\title{
Indirect determination of pediatric blood count reference intervals
}

\author{
Aus der Kinder- und Jugendklinik \\ Direktor: Prof. Dr. med. Dr. h. c. Wolfgang Rascher
}

Der Medizinischen Fakultät

der Friedrich-Alexander-Universität

Erlangen-Nürnberg

zur

Erlangung des Doktorgrades Dr. med.

vorgelegt von

Jakob Tobias Zierk

aus Hamburg 
Als Dissertation genehmigt von der Medizinischen Fakultät der Friedrich-Alexander-Universität Erlangen-Nürnberg

Tag der mündlichen Prüfung:

3.12.2015

Vorsitzender des Promotionsorgans:

Prof. Dr. med. Dr. h. c. Jürgen Schüttler

Gutachter:

Prof. Dr. med. Markus Metzler

Prof. Dr. med. Dr. h. c. Wolfgang Rascher

Prof. Dr. med. Michael Vogeser (Klinikum der Universität München)

Prof. Dr. med. Holger Cario (Universitätsklinikum UIm) 


\section{In Dankbarkeit gewidmet}

Meinen Eltern, Ursula Zierk und Dr. Thomas Bormann. 


\section{Inhaltsverzeichnis}

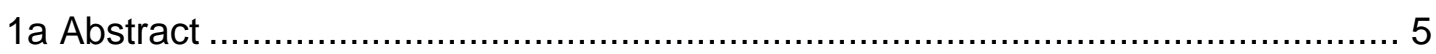

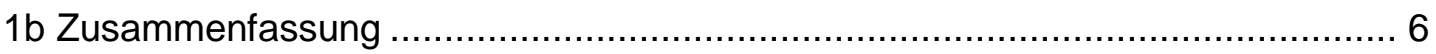

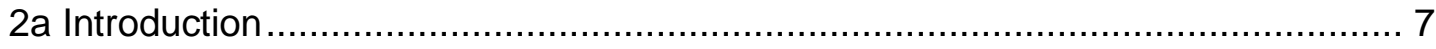

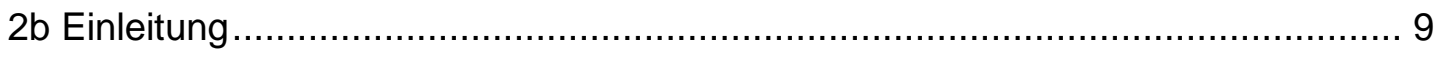

3 Vorveröffentlichung (mit separater Nummerierung) ........................................11

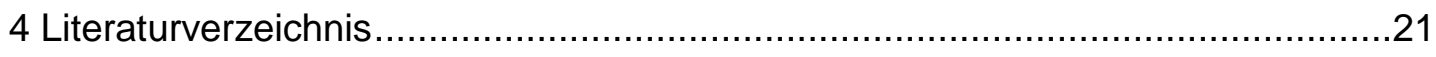

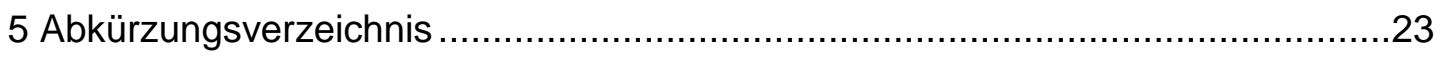

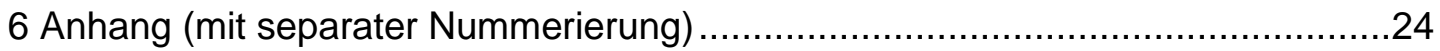

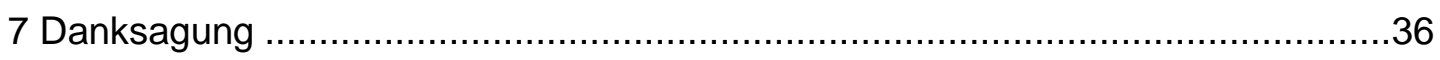

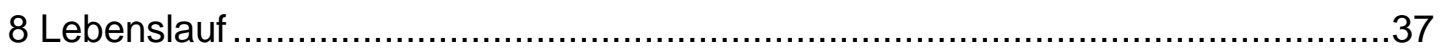




\section{1a Abstract}

Background: Determination of pediatric reference intervals (Rls) for laboratory quantities, including hematological quantities, is complex. The measured quantities vary by age, and obtaining samples from healthy children is difficult. Many widely used Rls are derived from small sample numbers and are split into arbitrary discrete age intervals. Use of intra-laboratory RIs specific to the examined population and analytical device used is not yet fully established. Indirect methods address these issues by deriving Rls from clinical laboratory databases which contain large datasets of both healthy and pathological samples.

Methods: A refined indirect approach was used to create continuous agedependent Rls for blood count quantities and sodium from birth to adulthood. The dataset for each quantity consisted of 60,000 individual samples from our clinical laboratory. Patient samples were separated according to age, and a density function of the proportion of healthy samples was estimated for each age group. The resulting RIs were merged to obtain continuous RIs from birth to adulthood.

Results: The obtained Rls were compared to Rls generated by identical laboratory instruments, and to population-specific Rls created using conventional methods. This comparison showed a high concordance of reference limits and their agedependent dynamics.

Conclusions: The indirect approach reported here is wellsuited to create continuous, intra-laboratory RIs from clinical laboratory databases and showed that the Rls generated are comparable to those created using established methods. The procedure can be transferred to other laboratory quantities and can be used as an alternative method for $\mathrm{RI}$ determination where conventional approaches are limited. 


\section{1b Zusammenfassung}

Hintergrund: Die Bestimmung pädiatrischer Referenzintervalle (RIs) für Laborgrößen einschließlich hämatologischer Größen ist komplex. Die gemessenen Werte sind altersabhängig und die Probengewinnung von gesunden Kindern ist problematisch. Viele verbreitete Rls basieren auf kleinen Stichprobenpopulationen und sind in arbiträre und diskrete Altersintervalle aufgeteilt. Die Verwendung von RIs, die zugleich labor-, analysemethoden- und populationsspezifisch sind, ist oft nicht möglich. Mit der Verwendung indirekter Methoden können Rls aus klinischen Labordatenbanken bestimmt werden, die große Datensätze pathologischer und nicht-pathologischer Messwerte enthalten.

Methoden: Mit einer weiterentwickelten indirekten Methode wurden kontinuierliche altersabhängige Rls für Parameter des Blutbilds und Natrium von Geburt bis zum Erwachsenenalter bestimmt. Für jede Messgröße standen mehr als 60.000 Messwerte aus unserem Routinelabor zur Verfügung. Die Patientenmesswerte wurden altersabhängig aufgeteilt und der Anteil nicht-pathologischer Messwerte mittels einer Dichtefunktion für jede Altersgruppe geschätzt. Die Rls wurden zu kontinuierlichen altersabhängigen RIs von Geburt bis Erwachsenenalter fusioniert.

Ergebnisse: Die ermittelten Rls wurden mit Analysemethode-spezifischen Rls sowie mit populationsspezifischen Rls verglichen, die mit konventionellen Methoden generiert wurden. Dieser Vergleich zeigte eine hohe Übereinstimmung.

Schlussfolgerungen: Der entwickelte indirekte Ansatz ist für die Bestimmung kontinuierlicher, labor- und populationsspezifischer Rls aus Labordatenbanken gut geeignet. Die generierten Rls sind vergleichbar mit konventionell bestimmten. Die Methode kann auf andere Laborwerte übertragen werden und ist eine Alternative zu konventionellen Methoden, insbesondere, wenn deren Anwendbarkeit eingeschränkt ist. 


\section{2a Introduction}

Determination of reference intervals (RIs) poses particular challenges in the pediatric population [1]. The dynamic anatomical and physiological development, particularly in the first years of life and during puberty, accounts for a high variability for many measured quantities with age. To accurately represent the age-dependent characteristics of such quantities, relatively large reference cohorts are required for the generation of Rls with an adequate ageresolution. The classical approach of sampling a healthy reference population and using the 2.5th and 97.5th percentiles as the lower or upper reference limit [2-4] can often not be applied to children. Reference populations such as healthy blood donors, often referred to when determining RIs for the adult population, are not readily available and ethical considerations would restrict blood sampling from healthy children for the purpose of reference interval generation [5].

Only few studies have embedded blood sampling in the context of a more comprehensive study objective, e.g., the Canadian CALIPER study (Canadian Laboratory Initiative on PEdiatric Reference Intervals) [6-8] and the German Health Interview and Examination Survey for Children and Adolescents (KiGGS), which collected 14,076 blood samples from a representative German cohort of children aged from 1 to 18 years [9]. The considerable effort associated with this study design makes it impossible, however, to apply this approach to any possible quantity and age group. Although clinically most relevant in neonatal medicine, the critical age group of newborns and young infants had been excluded by the KiGGS survey and other studies.

Therefore, in many laboratories, Rls have been adopted from values provided by the literature or the analyzer' s manufacturer irrespective of the underlying ethnical background of the reference population or additional influence factors due to methodological differences [10]. Even these RIs are often derived from very small sample sizes, well below the International Federation of Clinical Chemistry and Laboratory Medicine 's (IFCC) recommendation [10, 11].

Alternative approaches evading several of the above mentioned obstacles, apply algorithms to calculate RIs from laboratory values containing a mixture of healthy and pathological samples [12-17]. These methods are based on the assumption that the input dataset consists of a mixture of parametrically distributed samples from healthy individuals, and random pathologic samples. When applied to a sufficiently large dataset, these two sample sets can be reliably separated and the pathological samples have no significant impact on the healthy population 's RIs. The underlying 
parametric distribution of healthy samples is estimated by statistical methods, and its 2.5 th and 97.5 th percentile defines the RI.

Another shortcoming of conventional pediatric Rls is that age ranges are often arbitrarily chosen irrespective of developmental stages. In analogy to other developmental quantities, routinely specified in relation to age (e.g., height-for-age charts, blood pressure percentiles), a continuous description would also seem to be an appropriate approach for laboratory quantities.

The aim of the study was to augment previously developed algorithms for indirect RI calculation to create continuous Rls for pediatric laboratory quantities. The correctness of the generated Rls for hematologic quantities and sodium was tested by comparing them to Rls determined by established methods. 


\section{2b Einleitung}

Die Bestimmung von Referenzintervallen (RIs) ist komplex, dies gilt insbesondere in der Pädiatrie. Die dynamische anatomische und physiologische Entwicklung führt vor allem in den ersten Lebensjahren und in der Pubertät zu einer hohen altersabhängigen Variabilität vieler Messgrößen. Um diese Dynamik adäquat und genau abzubilden sind relativ große Referenzkohorten erforderlich. Die konventionelle Methode, eine gesunde Referenzpopulation zu messen und die 2,5. und 97,5. Perzentile als unteren bzw. oberen Referenzwert zu verwenden kann im Kindesalter oft nicht angewandt werden. In der Erwachsenenmedizin häufig verwandte Referenzpopulationen wie z.B. gesunde Blutspender sind nicht verfügbar und die Verwendung von Blutproben gesunder Kinder zum Zweck der Normwertgenerierung ist aus ethischen Gründen eingeschränkt.

In einigen wenigen Studien, wie z.B. der kanadischen CALIPER-Studie (Canadian Laboratory Initiative on PEdiatric Reference Intervals) und der deutschen KiGGSStudie (Studie zur Gesundheit von Kindern und Jugendlichen in Deutschland) wurden im Rahmen einer umfassenderen Fragestellung Blutabnahmen durchgeführt. In der KiGGS-Studie wurden 14.076 Blutproben von Kindern zwischen 1 und 18 Jahren aus einer repräsentativen deutschen Stichprobe gewonnen. Der mit diesen Studien verbundene Aufwand verhindert jedoch, diese Methode auf jede Laborgröße und Altersgruppe zu übertragen. Und obwohl die Altersgruppe der Neugeborenen und Säuglinge klinisch von höchster Relevanz ist, wurde diese Gruppe aus der KiGGS-Studie und anderen Studien ausgeschlossen.

Viele Laboratorien verwenden daher entweder publizierte Referenzintervalle oder vom Hersteller des verwendeten Analysegeräts zur Verfügung gestellte Angaben. Der ethnische Hintergrund der analysierten Population oder methodische Unterschiede können dabei nicht immer berücksichtigt werden. Selbst diese Referenzintervalle basieren jedoch oftmals auf Stichproben, die kleiner sind als von der IFCC (International Federation of Clinical Chemistry and Laboratory Medicine) empfohlen.

Um diese Probleme zu umgehen, wurden alternative Methoden entwickelt, die durch die Anwendung mathematischer Algorithmen die Ableitung von Rls aus Labordatenbanken erlauben. Diese Datenbanken enthalten sowohl pathologische Messwerte auch normale Messwerte, die zusammen eine Gesamtverteilung bilden. Sogenannte indirekte Methoden der Normwertgenerierung basieren auf der Annahme, dass diese Gesamtverteilung aus der Summe einer parametrischen (mathematisch beschreibbaren) Verteilung gesunder Messwerte und zufällig 
verteilten pathologischen Messwerten besteht. Bei Verwendung eines ausreichend großen Datensatzes können diese zwei Verteilungen mittels statistischer Methoden zuverlässig getrennt werden und das RI durch Berechnung der 2,5. und 97,5. Perzentile der Verteilung gesunder Messwerte berechnet werden.

Die Altersabhängigkeit pädiatrischer Rls wird meist durch die Einteilung in diskrete Altersgruppen abgebildet, diese Einteilung widerspricht der Vorstellung von Entwicklung als kontinuierlichem Prozess. Analog zu anthropometrischen Messgrößen (z.B. Perzentilekurven für altersbezogenenes Körpergewicht und -größe) erscheint die Verwendung kontinuierlicher Rls auch für Labormessgrößen adäquat.

In dieser Studie wurden Algorithmen zur indirekten Bestimmung von RIs weiterentwickelt um kontinuierliche, indirekte pädiatrische Rls zu berechnen. Die entwickelten RIs für hämatologische Messgrößen und Plasma-Natrium wurden durch einen Vergleich mit konventionell bestimmten Rls validiert. 


\section{Indirect determination of pediatric blood count reference intervals}

\section{Abstract}

Background: Determination of pediatric reference intervals (RIs) for laboratory quantities, including hematological quantities, is complex. The measured quantities vary by age, and obtaining samples from healthy children is difficult. Many widely used RIs are derived from small sample numbers and are split into arbitrary discrete age intervals. Use of intra-laboratory RIs specific to the examined population and analytical device used is not yet fully established. Indirect methods address these issues by deriving RIs from clinical laboratory databases which contain large datasets of both healthy and pathological samples.

Methods: A refined indirect approach was used to create continuous age-dependent RIs for blood count quantities and sodium from birth to adulthood. The dataset for each quantity consisted of 60,000 individual samples from our clinical laboratory. Patient samples were separated according to age, and a density function of the proportion of healthy samples was estimated for each age group. The resulting RIs were merged to obtain continuous RIs from birth to adulthood.

Results: The obtained RIs were compared to RIs generated by identical laboratory instruments, and to population-specific RIs created using conventional methods. This comparison showed a high concordance of reference limits and their age-dependent dynamics.

Conclusions: The indirect approach reported here is wellsuited to create continuous, intra-laboratory RIs from clinical laboratory databases and showed that the RIs generated are comparable to those created using established methods. The procedure can be transferred to other laboratory quantities and can be used as an alternative method for RI determination where conventional approaches are limited.

Keywords: blood count; hematology; indirect determination of reference intervals; pediatric reference intervals; reference range.

\author{
*Corresponding author: Markus Metzler, Department of Pediatrics, \\ University of Erlangen-Nuremberg, Loschgestr. 15, 91054 Erlangen, \\ Germany, Phone: +49 91318533783 , \\ E-mail: markus.metzler@uk-erlangen.de \\ Jakob Zierk, Wolfgang Rascher and Manfred Rauh: Department of \\ Pediatrics, University of Erlangen-Nuremberg, Erlangen, Germany \\ Farhad Arzideh: Department of Statistics, University of Bremen, \\ Bremen, Germany \\ Rainer Haeckel: Bremer Zentrum für Laboratoriumsmedizin, \\ Klinikum Bremen Mitte, Bremen, Germany
}

\section{Introduction}

Determination of reference intervals (RIs) poses particular challenges in the pediatric population [1]. The dynamic anatomical and physiological development, particularly in the first years of life and during puberty, accounts for a high variability for many measured quantities with age. To accurately represent the age-dependent characteristics of such quantities, relatively large reference cohorts are required for the generation of RIs with an adequate ageresolution. The classical approach of sampling a healthy reference population and using the 2.5th and 97.5th percentiles as the lower or upper reference limit [2-4] can often not be applied to children. Reference populations such as healthy blood donors, often referred to when determining RIs for the adult population, are not readily available and ethical considerations would restrict blood sampling from healthy children for the purpose of reference interval generation [5].

Only few studies have embedded blood sampling in the context of a more comprehensive study objective, e.g., the Canadian CALIPER study [6-8] and the German Health Interview and Examination Survey for Children and Adolescents (KiGGS), which collected 14,076 blood samples from a representative German cohort of children aged from 1 to 18 years [9]. The considerable effort associated with this study design makes it impossible, however, to apply this approach to any possible quantity and age group. Although clinically most relevant in neonatal medicine, the critical age group of newborns and young 
infants had been excluded by the KiGGS survey and other studies.

Therefore, in many laboratories, RIs have been adopted from values provided by the literature or the analyzer's manufacturer irrespective of the underlying ethnical background of the reference population or additional influence factors due to methodological differences [10]. Even these RIs are often derived from very small sample sizes, well below the International Federation of Clinical Chemistry and Laboratory Medicine's (IFCC) recommendation $[10,11]$.

Alternative approaches evading several of the above mentioned obstacles, apply algorithms to calculate RIs from laboratory values containing a mixture of healthy and pathological samples [12-17]. These methods are based on the assumption that the input dataset consists of a mixture of parametrically distributed samples from healthy individuals, and random pathologic samples. When applied to a sufficiently large dataset, these two sample sets can be reliably separated and the pathological samples have no significant impact on the healthy population's RIs. The underlying parametric distribution of healthy samples is estimated by statistical methods, and its 2.5th and 97.5th percentile defines the RI.

Another shortcoming of conventional pediatric RIs is that age ranges are often arbitrarily chosen irrespective of developmental stages. In analogy to other developmental quantities, routinely specified in relation to age (e.g., height-for-age charts, blood pressure percentiles), a continuous description would also seem to be an appropriate approach for laboratory quantities.

The aim of the study was to augment previously developed algorithms for indirect RI calculation to create continuous RIs for pediatric laboratory quantities. The correctness of the generated RIs for hematologic quantities and sodium was tested by comparing them to RIs determined by established methods.

\section{Materials and methods}

\section{Data source}

All blood counts performed during a 29-month period at the University Children's Hospital Erlangen - a tertiary care center covering the entire spectrum of pediatrics - were retrieved from the laboratory's database. For each quantity, between 56,253 and 60,394 measurements were available (see Supplemental Table 1, which accompanies the article at http://www.degruyter.com/view/j/cclm.2013.51.issue-7/ issue-files/cclm.2013.51.issue-7.xml). Stratification according to ethnicity was not performed; distinct RIs for different ethnic groups are not established in Germany. The composition of the population in
Germany is mainly influenced by migration of individuals of Caucasian origin.

Blood counts were performed on a Sysmex XE-2100 hematological analyzer (Sysmex Europe). The quantities examined were hemoglobin, hematocrit, red cell count, mean red cell volume (MCV), mean red cell hemoglobin ( $\mathrm{MCH})$, mean red cell hemoglobin concentration (MCHC), platelet count, red cell distribution width variation coefficient (RDWCV).

Data was also collected for plasma sodium. Sodium was chosen for comparison as it is a quantity which is largely stable during development, and its measurement is well-standardized. Plasma sodium measurements were performed on a COBAS Integra 800 (Roche Diagnostics).

Measurement accuracy and precision data is available in Supplemental Table 2 . The stability of each quantity over time during the study period is demonstrated by stable monthly median values (Supplemental Table 3).

Two different data sets were created and compared in order to explore the stability of the method regarding the influence of pathologic samples: one containing the complete data set and another in which samples from patients in intensive care units and oncological units were excluded (41,517-42,848 samples).

\section{Calculation of continuous reference intervals}

The calculation of continuous RIs was performed in three steps: First, the data was split into overlapping time frames. Discrete RIs for each time frame were generated using an algorithm published earlier by Arzideh et al. [12, 13]. These calculated RIs were plotted in time/ value graphs and continuous splines were fitted.

\section{Timeline generation}

For each quantity, all the samples were collated and split into overlapping 'time frames', each containing 750 samples (Figure 1B). When multiple samples were available from a single patient, only one sample was included in each time frame (Supplemental Figure 1). A sample count of 750 was chosen because pilot tests showed that 750 samples were the optimum compromise for accuracy and resolution (data not shown). This resulted in 122-127 time frames for each quantity, and 114-117 time frames when patients from intensive care units and oncology units were excluded (Supplemental Table 1). Due to the age distribution of our hospital population, time frames contain measurements for age groups spanning different time ranges, depending on the number of patients within a certain age interval (e.g., the hemoglobin frame for age=1 day contains only values for age $=1$ day while the frame for age $=12.1$ years contains values from 11.7 to 12.5 years).

\section{Calculation of RIs}

For the analysis of the data of single time frames, an expanded version of the algorithm developed by Arzideh et al. was used $[12,13]$. Briefly, to obtain a non-parametrical function of the sample value distribution, a smoothed kernel density function is estimated 

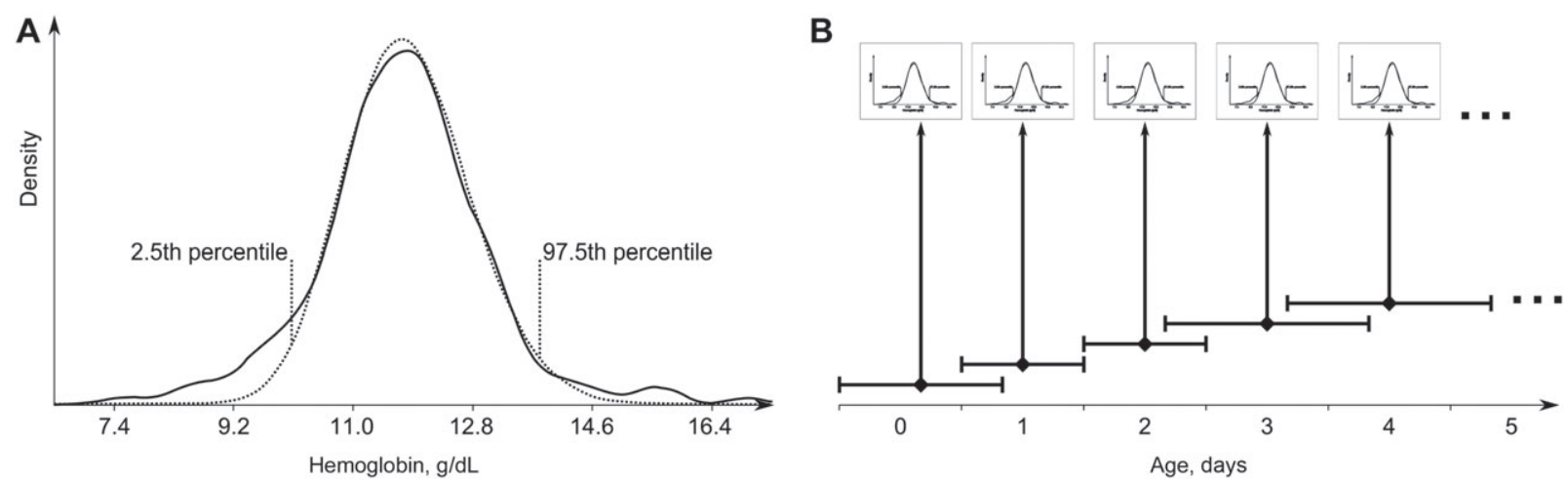

Figure 1 Algorithm for the creation of continuous RIs.

(A) Typical analysis of the samples of a single time frame. This figure shows the calculation of the hemoglobin RI for male patients between age $=86$ days and age $=212$ days. The black line shows the kernel density estimation (kde) of hemoglobin value incidences. Into this kde the optimal Box-Cox distribution was fitted and the 2.5th and 97.5 th percentiles for this distribution were calculated (gray line). (B) Timeline generation: For each time frame generated, separate RIs were calculated.

Data are presented in conventional units; factors for converting to SI units are as follows: hemoglobin, $1 \mathrm{mg} / \mathrm{dL}=0.6206 \mathrm{mmol} / \mathrm{L}$.

(Figure 1A). The resulting data set is assumed to consist of three subgroups, the non-diseased ('healthy'), and two subgroups with values lower and higher than those of the non-diseased subgroup. The subset of non-diseased samples is modeled using a Box-Cox transformed truncated normal distribution. The Box-Cox transformation is used to transform 'skewed' distributions into symmetrical distributions and is defined as follows:

$$
\begin{gathered}
\mathrm{Y}=\log \mathrm{X}(\mathrm{X}>0, \lambda=0) \\
\mathrm{Y}=1 / \lambda \times\left(\mathrm{X}^{\lambda}-1\right)(\mathrm{X}>0, \lambda \neq 0)
\end{gathered}
$$

The two subgroups with lower and higher values are assumed to be non-parametrical functions. The parameters for the Box-Cox transformation and the truncated normal distribution are estimated using an optimization method (maximum likelihood method). This results in a parametrical distribution of the non-diseased samples. The distribution's 2.5th and 97.5th percentiles are calculated to obtain RIs [13]. This step is performed for each quantity and for each time frame (Figure 1).

\section{Creation of continuous splines}

For each quantity, parametric curves for the 2.5th and 97.5th percentile were generated, one for the first 180 days of life and one for the remaining time span from 180 days to 18 years (Figure $2 \mathrm{~A}$ and $\mathrm{B}$ ). The $\mathrm{R}$ software's 'smooth.spline' method was used to convert the RI points into a smooth spline [18]. This method was chosen as no assumptions are made about the model behind the data, and the upper and lower reference ranges are drawn independently.

\section{Results}

Continuous indirect RIs (iRIs) from birth to adulthood were created for hemoglobin concentration, hematocrit, red cell count, erythrocyte indices, RDWCV, platelet count and plasma sodium. The iRIs were analyzed for the influence of sample selection, were compared to instrument-specific RIs and to RIs determined using a validated approach.

\section{Influence of sample selection}

Generation of indirect RIs is based on the assumption that the portion of pathological samples has no significant influence on the generated RIs $[13,14]$. Within a pediatric hospital's population, patients from intensive care units and oncological departments are expected to contain the largest proportion of pathological samples, particularly concerning blood cell count and electrolytes. Two different datasets were created, one containing all samples and one in which samples from patients in intensive care units and oncological units were removed to test the influence of sample selection.

Figure 2B shows a comparison of the resulting iRIs for hemoglobin, Figures for all other quantities are available in the Supplemental Data (Supplemental Figures 2-9). There is no difference in the iRIs after 180 days, whether samples from intensive care units and oncological units are removed, or not. All further analyses were therefore performed on the unfiltered data set.

In the first 180 days of life there is an apparent difference, which is especially pronounced in the first 100 days of life for the hemoglobin, red cell count and RDWCV RIs. This difference is attributable to the comparison of two different populations (preterm infants and term infants) which are not usually differentiated in clinical laboratory practice. 
A

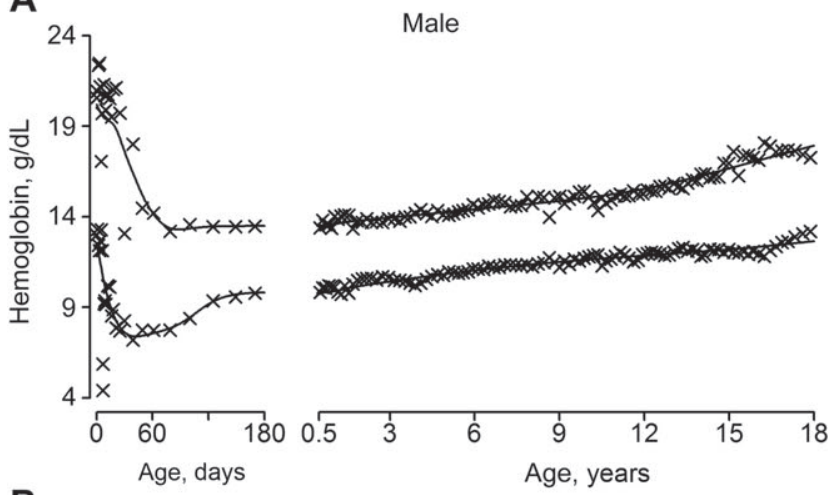

B

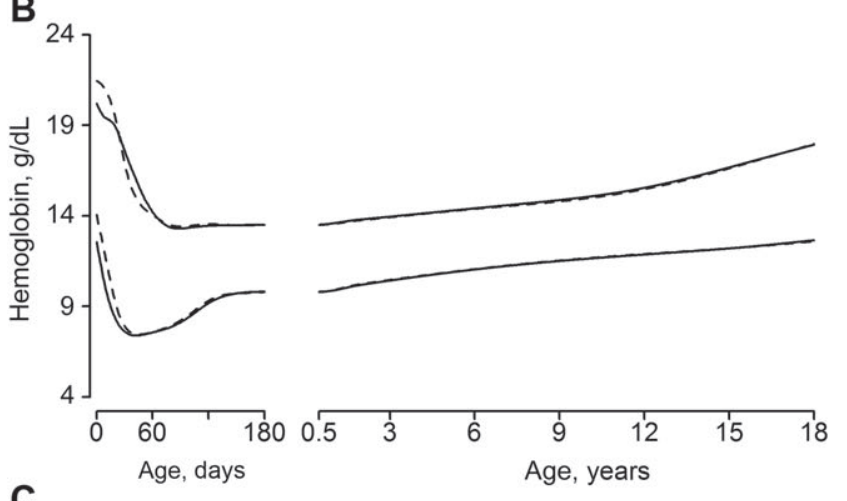

C

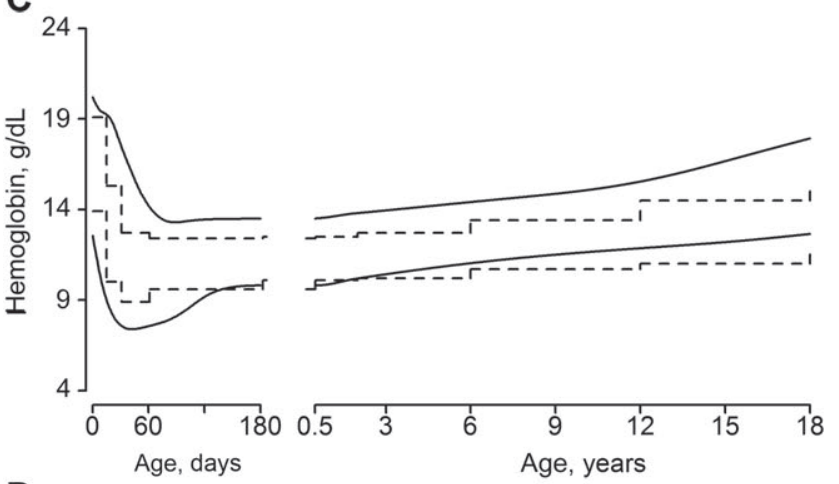

D

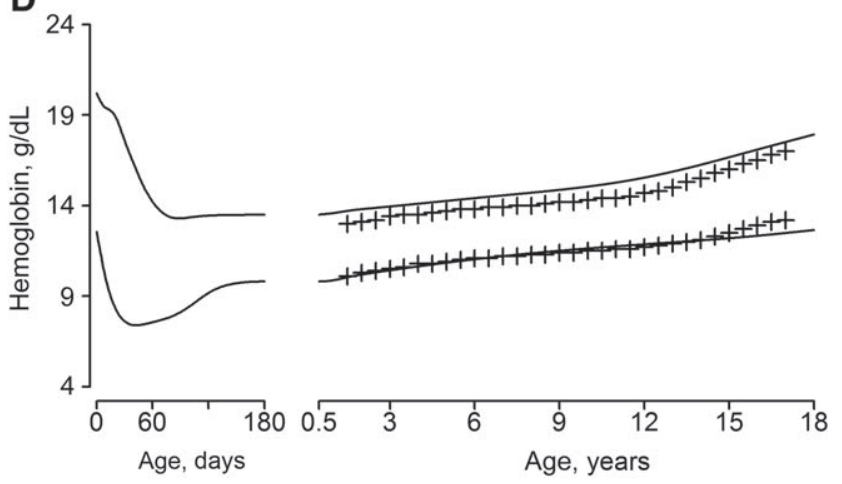

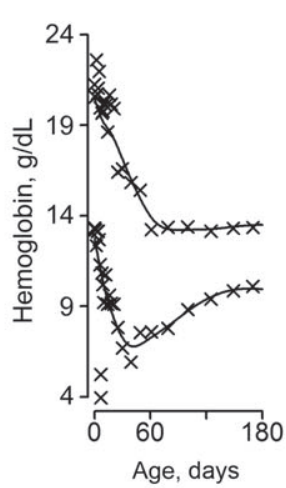

Female
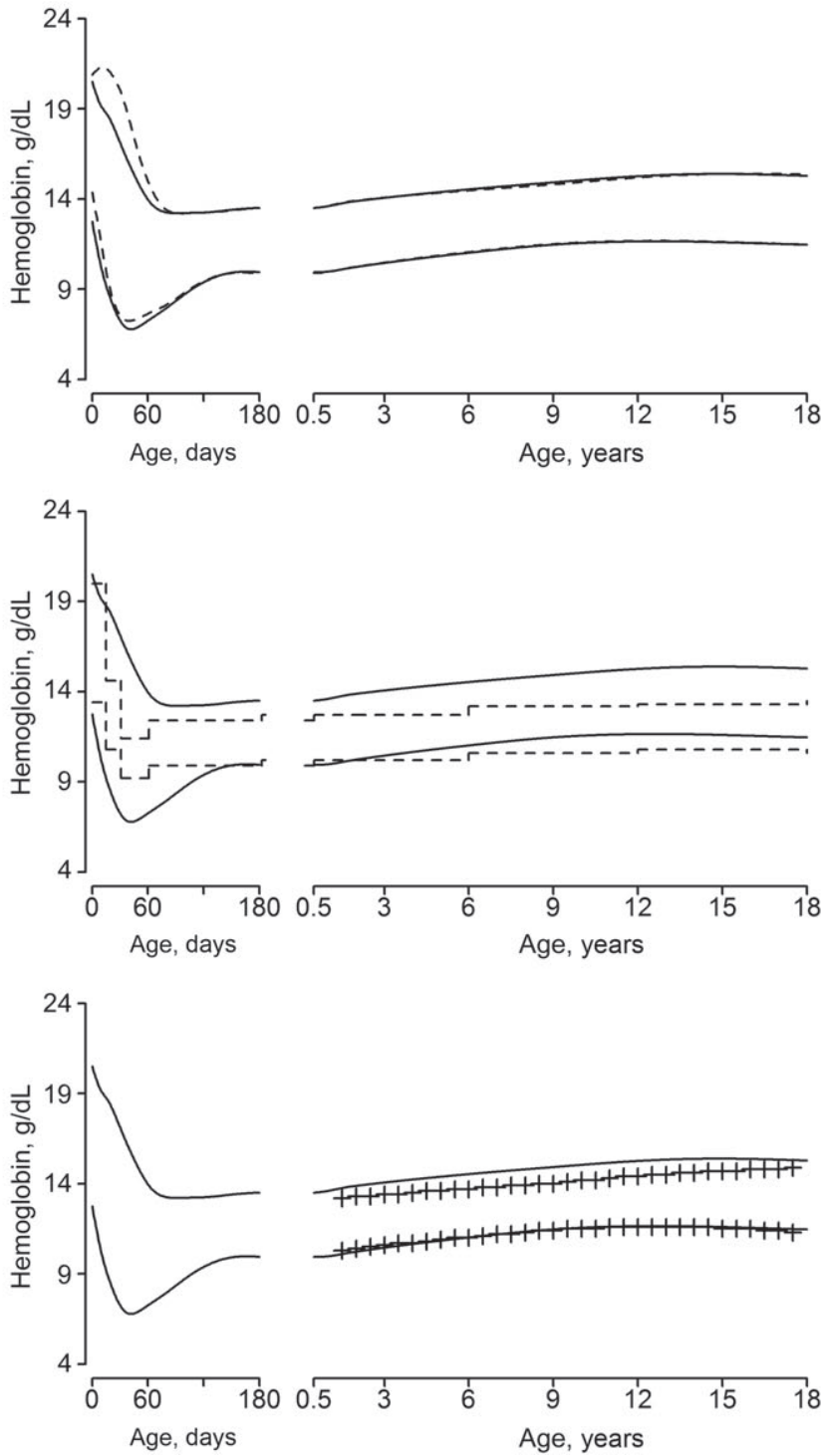

Figure 2 Calculation of hemoglobin RIs.

(A) Fitting a continuous spline (continuous line) to the discrete Hemoglobin RIs (crosses). (B) Comparison of calculated hemoglobin RIs. (Continuous line=All samples; Dashed black line=Samples from intensive care units/oncological units removed). (C) Calculated Hemoglobin RIs (continuous line) versus RIs provided by the manufacturer (dashed line) [11]. (D) Calculated Hemoglobin RIs (continuous line) versus RIs determined in the KiGGS study (crosses) [9]. Data are presented in conventional units; factors for converting to SI units are as follows: hemoglobin, $1 \mathrm{mg} / \mathrm{dL}=0.6206 \mathrm{mmol} / \mathrm{L}$. KiGGS, German Health Interview and Examination Survey for Children and Adolescents. 


\section{Comparison with instrument-specific RIs}

Comparison of different RIs is hampered by differences in methodology. RIs generated on the same analyzer system provided by the manufacturer were compared to the indirect RIs from our cohort. Figure 3 shows all iRIs, Figure $2 \mathrm{C}$ shows the hemoglobin iRIs in comparison with those provided by the analyzer's manufacturer [11]. Figures for all quantities are available in the Supplemental Data (Supplemental Figures 2-9).

The calculated iRIs show curves similar to the RIs supplied by the manufacturer but differ in terms of exact placement on the y-axis. This displacement is especially pronounced in the first 180 days of life, resulting from two main factors. As discussed above, the differences are to be expected, as different populations are studied. In addition, the sample sizes underlying the instrument-specific RIs are very low ( $\mathrm{n}=37-116$ for age groups younger than 60 days, $n=44-1955$ for older children) [11] in comparison to the sample size from our cohort $(n \geq 750)$.

\section{Comparison with RIs from the KiGGS study}

Indirect methods for creating RIs have been criticized due to the lack of a precise definition of the reference population, the frequent failure to create RIs for non-normal distributions and being not applicable to laboratories other than the originating one [19]. A comparison with results determined using validated methods is therefore essential to assess the reliability of the indirect method applied in this study. For this comparison, the results of the KiGGS study were chosen, in which 14,076 blood samples were drawn from a representative German cohort, and percentile charts generated for children aged from 1 to 18 years; a stratification according to the ethnic background of the children was not performed [9]. (RIs for children under the age of 1 year were not included in the study, platelets, RDWCV and plasma sodium were not measured. Blood samples were taken either sitting or lying throughout the day and children were not required to be fasting. Analysis of hemoglobin concentration, red cell count, red cell indices and hematocrit was performed on an Abbott Cell-Dyn 3500).

Due to the large amount of data available we could also create RIs for the first 180 days of life; data for this age group are missing in the KiGGS study.

Figure 2D shows the hemoglobin iRIs in comparison to the RIs determined in the KiGGS study (the 3rd and 97th percentile were used for iRIs and KiGGS RIs, Figures for the other comparisons are available in the Supplemental Data, Figures 2-9). The computed differences between the iRIs and the KiGGS RIs are shown in Table 1.

The hemoglobin, hematocrit and red cell count RIs are visually parallel, the lower RIs are nearly equivalent, the upper RIs diverge by about $0.6 \mathrm{~g} / \mathrm{dL}(0.37 \mathrm{mmol} / \mathrm{L}), 1.9 \%$, $0.2 \times 10^{6} / \mu \mathrm{L}\left(0.2 \times 10^{12} / \mathrm{L}\right)$, respectively. The MCV RIs also run parallel, although the upper iRIs tend to be higher, especially for female children. Also, the RIs generated by the KiGGS study show an ascending slope for the MCV RIs in the first 6 years of life, which is less pronounced in the iRIs. Except for an ascending slope for male MCH lower KiGGS RIs in the first 4 years of life, which has no representation in our iRIs, the MCH iRIs are congruent to the KiGGS RIs. The upper iRI curve for MCHC is congruent to the KiGGS RI curve, the lower iRI curve is shifted by about $1-2 \mathrm{~g} / \mathrm{dL}$.

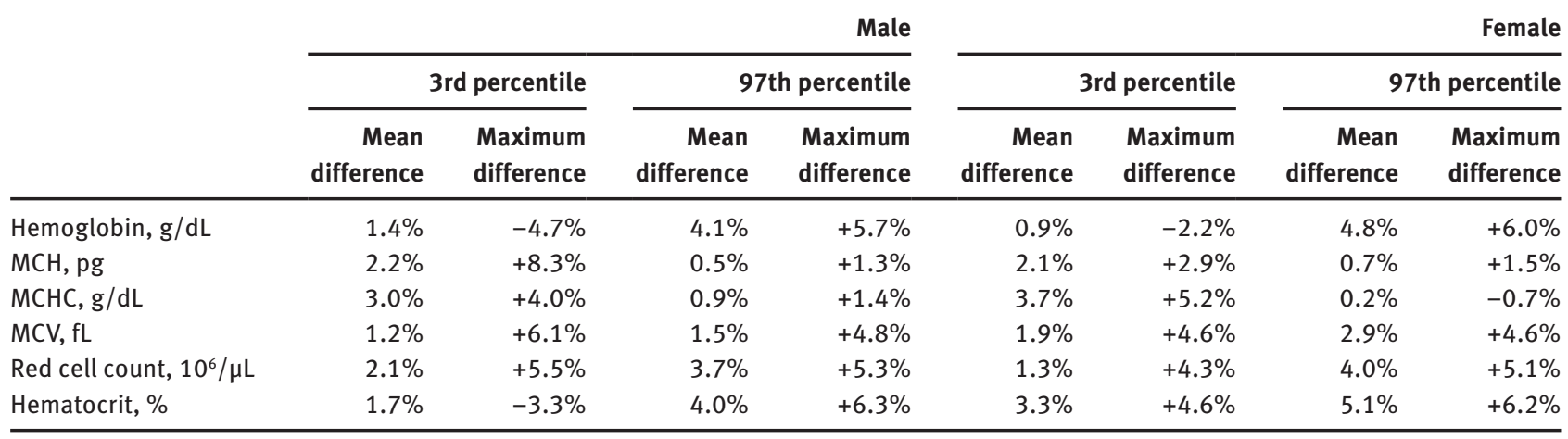

Table 1 Relative differences between the calculated RIs and the RIs from the KiGGS study.

The relative difference of the RIs calculated using our indirect method and the RIs published in the KiGGS study [9] was calculated. For each quantity, the difference between our RIs and KiGGS RIs was calculated for age $=1.5$ years to age $=17.5$ years (in steps of 0.5 years). The mean (without sign) and maximum difference (with sign) of 3rd and 97th percentile is depicted above. KiGGS, German Health Interview and Examination Survey for Children and Adolescents); MCH, mean red cell hemoglobin; MCHC, mean red cell hemoglobin concentration; MCV, mean red cell volume. 

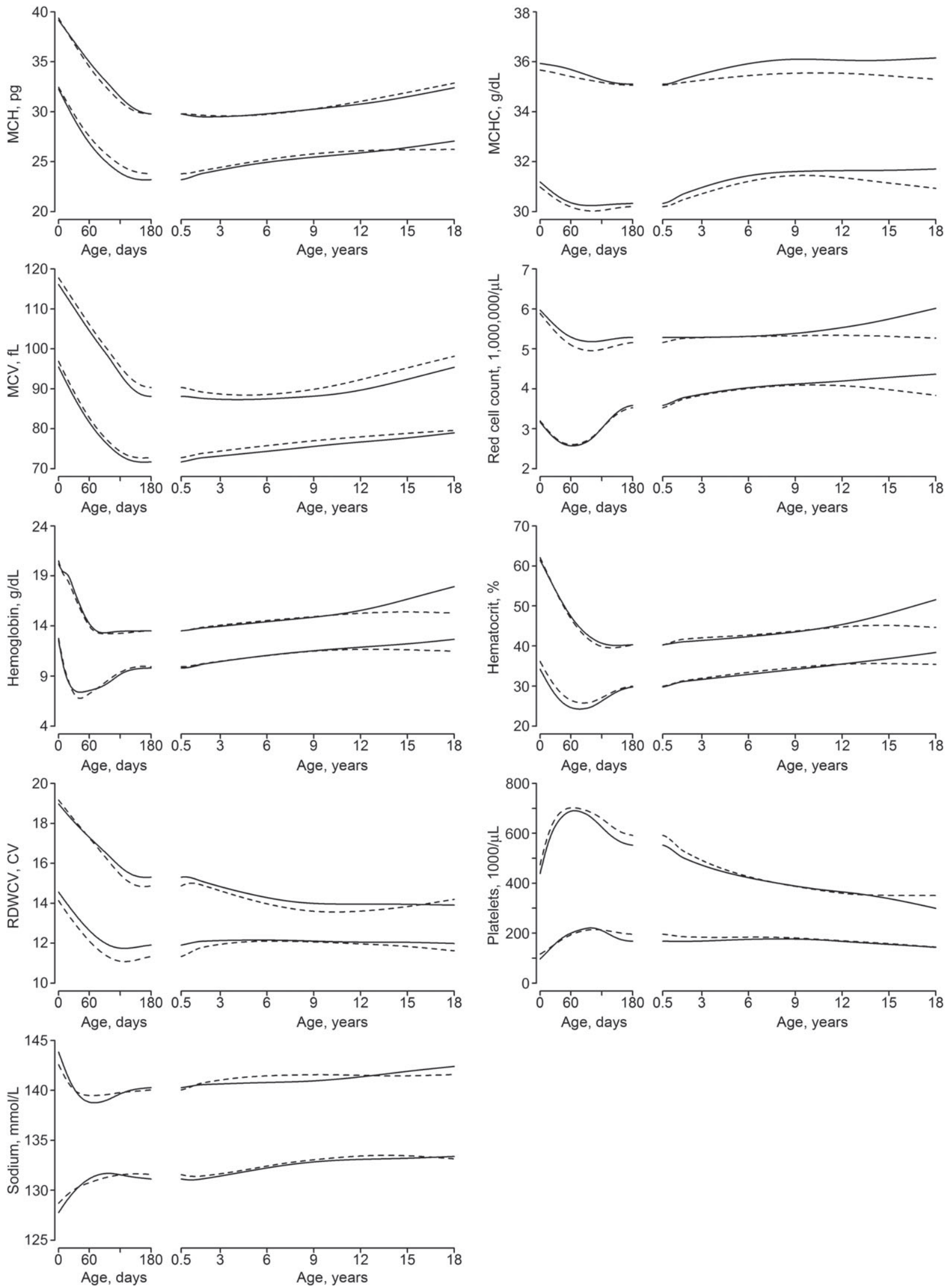

Figure 3 Calculated RIs.

Continuous lines: male RIs; dashed lines: female RIs. Data are presented in conventional units; factors for converting to SI units are as follows: hemoglobin, $1 \mathrm{mg} / \mathrm{dL}=0.6206 \mathrm{mmol} / \mathrm{L}$. 
Differences between the calculated iRIs and the RIs generated using validated methods are in the range of allowed measurement uncertainty (Table 1), i.e., the guidelines of the German Medical Association for laboratory quality control [20] allow a measurement inaccuracy for hemoglobin, hematocrit, red cell count and sodium of $4.0 \%, 5.0 \%, 4.0 \%$ and $3.0 \%$, respectively. Overall, the two different approaches show a near-exact match.

\section{Comparison with RIs calculated using a healthy control group}

To enable the comparison to population- and methodspecific RIs we calculated RIs using the conventional approach of sampling a group of healthy children. Outpatient children presenting to our hospital for elective electroencephalography and endocrinology or neuropediatric evaluation (8 and 16 years) and out-patient children presenting to our hospital for elective electroencephalography, endocrinology or neuropediatric evaluation and elective surgery (160 days) were sampled. The 2.5th and 97.5th percentile of the resulting distribution after the elimination of outliers (Tukey's method) and the associated $95 \%$ confidence interval were calculated and compared to the indirect RIs (Table 2). The comparison shows that the great majority of calculated RIs are within the expected bounds.

\section{Continuity}

Most RIs currently used are valid for discrete intervals. This approach is reasonable, as it is impractical to create RIs using established methods for every possible age. The extension of the indirect method for RI determination allows the creation of continuous RIs for each quantity, especially important in pediatrics. (Supplemental Table 4 contains a summary of the calculated RIs, tables containing distinct upper and lower reference limits for each day of life from birth to 18 years are available as a downloadable Supplemental Data file, Supplemental Data Table (Reference Intervals).zip.

\section{Discussion}

For clinical decision making, the availability of reliable RIs is crucial. While technical advances have improved the precision of available laboratory tests and enabled their widespread employment, the task of generating RIs remains challenging. Applying the conventional approach of establishing reference ranges by sampling a healthy reference population to pediatric laboratory quantities is laborious, ethically challenging and often not possible. There are therefore few age-specific RIs for the pediatric population and especially for neonates. Those pediatric RIs available are often heterogeneous and created decades ago using small reference populations. Standard textbooks [21, 22] and current guidelines for the diagnosis of childhood anemia [23] refer to hemoglobin RIs created in 1978 using a Finnish cohort of as few as 52 children in certain age groups [24]. In this context, the development of in-house, instrument-specific pediatric RIs with sufficient age-resolution using conventional methods seems especially challenging.

These problems have led to the development of alternative approaches for RI creation. Indirect methods based on hospital databases, containing both pathological and non-pathological samples, have been proposed and used [12-17]. Arzideh et al. have applied an indirect method to create valid RIs for creatinine and electrolytes [12, 13]. In these instances a homogenous population was examined and the problem of age-dependent RIs did not have to be considered. The feasibility of generating continuous hemoglobin concentration RIs based on a hospital population was demonstrated by Virtanen et al. [25], although in this case the separation of healthy and pathological samples was performed manually.

We augmented an indirect method to create continuous RIs from birth to adulthood. As proof of concept, we generated RIs for blood count quantities and compared them to existing RIs. The pediatric blood count was chosen, as it is one of the most commonly performed laboratory tests and its quantities are very important in clinical decision making. It is subject to significant and rapid change during development, making fine-grained age-resolution essential. Yet despite its importance in clinical decision making and its pervasiveness, available RIs are heterogeneous.

The results of the German KiGGS study were chosen for comparison. Those RIs were determined by direct methods, as recommended by the IFCC, using a sufficiently large sample size of 14,076 blood samples and represent the best available RIs for German children. Comparison of the RIs created using our approach and those generated in the KiGGS study shows only minor differences. Despite the considerable effort invested in this study, RIs for neonates and infants up to 12 months could not be established. Using our indirect approach, it was possible to create continuous RIs from birth to 18 years with sufficient resolution in the first weeks of life. 


Male, 160 days

Platelets, $1000 / \mu \mathrm{L}$

Hematocrit, \%

$\mathrm{MCH}, \mathrm{pg}$

Hemoglobin, g/dL

MCV, fL

MCHC, g/dL

Red blood cells, $10^{6} / \mu \mathrm{L}$

Female, 160 days

RDWCV, CV

Platelets, $1000 / \mu \mathrm{L}$

Hematocrit, \%

$\mathrm{MCH}, \mathrm{pg}$

Hemoglobin, $\mathrm{g} / \mathrm{dL}$

MCV, fL

MCHC, g/dL

Red blood cells $10^{6} / \mu \mathrm{L}$

Male, 8 years

RDWCV, CV

Platelets, $1000 / \mu \mathrm{L}$

Hematocrit, \%

$\mathrm{MCH}, \mathrm{pg}$

Hemoglobin, $\mathrm{g} / \mathrm{dL}$

MCV, fL

MCHC, g/dL

Red blood cells, $10^{6} / \mu \mathrm{L}$

Female, 8 years

RDWCV, CV

Platelets, $1000 / \mu \mathrm{L}$

Hematocrit, \%

MCH, pg

Hemoglobin, g/dL

MCV, fL

MCHC, g/dL

Red blood cells, $10^{6} / \mu \mathrm{L}$

Male, 16 years

RDWCV, CV

Platelets, $1000 / \mu \mathrm{L}$

Hematocrit, \%

$\mathrm{MCH}, \mathrm{pg}$

Hemoglobin, g/dL

MCV, fL

MCHC, g/dL

Red blood cells, $10^{6} / \mu \mathrm{L}$

224

232

232

232

232

232

232

232

167

169

169

169

169

169

169

169

Female, 16 years

RDWCV, CV

Platelets, $1000 / \mu \mathrm{L}$

122

Hematocrit, \%

$\mathrm{MCH}, \mathrm{pg}$

Hemoglobin, g/dL

MCV, fL 2.5th percentile

Indirect method Control group $(95 \% \mathrm{Cl})$

Control group $(95 \% \mathrm{Cl})$
15.3

565

40.1

30

13.5

89

35

5.3

$11.9(11.5-12.1)$

134 (132-252)

$30.6(28.7-31.6)$

$25(23-25)$

$9.9(9.4-10.2)$

$76(72-77)$

$30(30-31)$

$3.5(3.4-3.8)$

$12.3(12.2-12.3)$

191 (172-210)

$34.0(33.8-34.7)$

25 (24-25)

$11.2(10.9-11.8)$

$75(73-76)$

$32(32-32)$

$4.1(4.0-4.2)$

$12.1(11.8-12.1)$

$194.3(176-212)$

$34.6(34.1-35.7)$

$26(26-26)$

$11.5(11.3-11.7)$

77 (76-78)

$32(32-32)$

$4.0(4.0-4.1)$

$12.2(12.0-12.4)$

$153(136-164)$

$36.3(35.0-37.3)$

$26(25-26)$

$12.3(11.4-12.6)$

$76(74-77)$

$31(30-32)$

$4.3(4.2-4.6)$

$12(11.6-12.2)$

$126(114-158)$

$35.2(34.6-37.1)$

$26(26-27)$

$11.5(11.4-12.1)$

$80(78-81)$
14.8

605

39.7

30

13.4

91

35

5.1

14.0

394

43.2

30

14.8

88

36

5.4

13.6

393

43.5

30

14.9

90

36

5.3

13.9

320

49.8

32

17.3

94

36

5.9

14.0

351

44.9

32

15.3

97 97.5th percentile

Control group $(95 \% \mathrm{Cl})$

$15.5(15.0-16.1)$

$515(473-557)$

$43.0(41.4-43.6)$ $30(29-30)$

$13.9(13.2-14.3)$

91 (88-92)

$35(34-35)$

$5.3(5.1-5.5)$

$15.4(14.9-16.0)$

$568(495-603)$

$41.5(39.3-42.2)$

$30(30-31)$

13.6 (13.1-15.0)

$92(91-93)$

$35(34-35)$

$5.0(4.9-5.2)$

14.3 (14.2-14.4)

$379(367-399)$

43.4 (42.7-43.8)

$30(30-31)$

14.8 (14.5-15.5)

$90(88-91)$

$36(36-37)$

$5.4(5.3-5.6)$

$14.2(14.0-14.4)$

$439(416-447)$

$42.9(42.3-44.7)$

$30(30-31)$

$14.4(14.2-14.6)$

$90(90-91)$

$35(35-35)$

$5.3(5.2-5.4)$

$14.7(14.2-14.9)$

$344.7(319-373)$

50.2 (48.9-51.6)

$31(31-32)$

$17.0(16.4-17.4)$

95 (93-98)

$36(35-36)$

$5.8(5.6-5.9)$

$14.9(14.6-15.0)$

$390(349-400)$

$45.6(44.7-46.7)$

$32(31-32)$

$15.2(14.8-15.7)$

$96(94-99)$ 
(Table 2 Continued)

\begin{tabular}{|c|c|c|c|c|c|}
\hline & \multirow[t]{2}{*}{$\mathbf{n}$} & \multicolumn{2}{|r|}{ 2.5th percentile } & \multicolumn{2}{|r|}{ 97.5th percentile } \\
\hline & & Indirect method & Control group $(95 \% \mathrm{Cl})$ & Indirect method & Control group $(95 \% \mathrm{Cl})$ \\
\hline $\mathrm{MCHC}, \mathrm{g} / \mathrm{dL}$ & 122 & 31 & $31(31-32)$ & 35 & $35(35-35)$ \\
\hline Red blood cells, $10^{6} / \mu \mathrm{L}$ & 122 & 3.9 & $3.9(3.9-4.2)$ & 5.3 & $5.2(5.1-5.3)$ \\
\hline
\end{tabular}

Table 2 Comparison of indirect RIs with RIs calculated using a healthy control group.

The RIs calculated using the presented indirect method were compared to Rls determined using the conventional approach of sampling a healthy group of children. Out-patient children presenting for elective electroencephalography and endocrinology or neuropediatric evaluation (8 and 16 years) and out-patient children presenting for elective electroencephalography, endocrinology or neuropediatric evaluation and elective surgery (160 days) were sampled. The 2.5th and 97.5 th percentile of the resulting distribution after the elimination of outliers (Tukey's method) and the associated $95 \%$ confidence interval are shown (n denotes the number of samples in the healthy control group). $\mathrm{MCH}$, mean red cell hemoglobin; MCHC, mean red cell hemoglobin concentration; MCV, mean red cell volume; RDWCV, red cell distribution width variation coefficient.

The high concordance to RIs created using established methods is also reflected by the precise overlap of physiological landmarks, such as the Physiologic Anemia of Infancy between weeks 7 and 14 and the gender-specific diversion of, e.g., hemoglobin concentration after the age of 10 years. Also, the indirect RIs show the steep increase in platelets during the first $1-2$ months after birth and the following decline. The decrease in fetal red blood cells is shown by a corresponding drop in MCH and MCV until about 5-6 months. The ability of our method to capture these biologic events is a strong indicator of its correctness. Plasma sodium representing less age-dependent quantities shows the expected constant RIs.

Unlike most common RIs for laboratory quantities - which are defined for discrete age intervals - the RIs developed using our approach are continuous from birth to adulthood. This seems sensible, as the underlying physiological changes which influence laboratory quantities are also continuous states rather than abrupt events.

We conclude that the approach presented generates valid RIs and can be used as an alternative, when conventional methods cannot be applied. Possible applications are the generation of RIs where none exist or when those available are of poor quality. Furthermore, the generation of RIs for defined subgroups such as ethnic populations, or children with chronic diseases is possible. With additional information the development of RIs stratified by gestational age is also possible.
Albeit less pronounced than during the first two decades of life, most laboratory quantities are subject to age-dependent variation from birth to old age. The use of age-dependent RIs should therefore not be restricted to pediatrics, but be expanded to adult medical specialties, particularly with respect to the increasing elderly patient population resulting from demographic change.

\section{Conclusions}

An extended indirect method was developed to generate continuous RIs from birth to adulthood with an excellent concordance to conventionally created RIs. This approach enables the establishment of RIs for a wider range of quantities and population groups where the conventional concept of RI creation is limited.

\section{Conflict of interest statement}

Authors' conflict of interest disclosure: The authors stated that there are no conflicts of interest regarding the publication of this article. Research funding: None declared. Employment or leadership: None declared. Honorarium: None declared.

Received October 10, 2012; accepted January 10, 2013; previously published online February 14, 2013

\section{References}

1. Ceriotti F. Establishing pediatric reference intervals: a challenging task. Clin Chem 2012;58:808-10.

2. Solberg HE. A guide to IFCC recommendations on reference values. J Int Fed Clin Chem 1993;5:162-5.

3. Jones G, Barker A. Reference intervals. Clin Biochem Rev 2008;29(Suppl 1):S93-7.
4. Horowitz GL, Altaie S, Boyd JC, Ceriotti F, Garg U, Horn P, et al. Defining, establishing, and verifying reference intervals in the clinical laboratory; Approved guideline, 3rd ed. Wayne, PA: Clinical and Laboratory Standards Institute, 2008.

5. Abdelhaleem M, Adeli K, Bamforth F, Callahan J, Chan A, Cheung Chan P, et al., An editorial on behalf of the CALIPER investigators. 
Pediatric reference intervals: critical gap analysis and establishment of a national initiative. Clin Biochem 2006;39:559-60.

6. Jung B, Adeli K. Clinical laboratory reference intervals in pediatrics: the CALIPER initiative. Clin Biochem 2009;42:1589-95.

7. Kulasingam V, Jung BP, Blasutig IM, Baradaran S, Chan MK, Aytekin M, et al. Pediatric reference intervals for 28 chemistries and immunoassays on the Roche cobas 6000 analyzer - a CALIPER pilot study. Clin Biochem 2010;43:1045-50.

8. Colantonio DA, Kyriakopoulou L, Chan MK, Daly CH, Brinc D, Venner AA, et al. Closing the gaps in pediatric laboratory reference intervals: a CALIPER database of 40 biochemical markers in a healthy and multiethnic population of children. Clin Chem 2012;58:854-68.

9. Dortschy R, Rosario AS, Scheidt-Nave C, Thierfelder W, Thamm $M$, Gutsche J, et al. Bevölkerungsbezogene Verteilungswerte ausgewählter Laborparameter aus der Studie zur Gesundheit von Kindern und Jugendlichen in Deutschland (KiGGS). Berlin: Robert Koch-Institut, 2009.

10. Friedberg RC, Souers R, Wagar EA, Stankovic AK, Valenstein PN The origin of reference intervals. Arch Pathol Lab Med 2007;131:348-57.

11. Soldin SJ, Brugnara C, Wong EC. Pediatric reference ranges, 4th ed. Washington, DC: AACC Press, 2003.

12. Arzideh F, Brandhorst G, Gurr E, Hinsch W, Hoff T, Roggenbuck $L$, et al. An improved indirect approach for determining reference limits from intra-laboratory data bases exemplified by concentrations of electrolytes. J Lab Med 2009;33:52-66.

13. Arzideh F, Wosniok W, Haeckel R. Reference limits of plasma and serum creatinine concentrations from intra-laboratory data bases of several German and Italian medical centres: comparison between direct and indirect procedures. Clin Chim Acta 2010;411:215-21.
14. Concordet D, Geffre A, Braun JP, Trumel C. A new approach for the determination of reference intervals from hospital-based data. Clin Chim Acta 2009;405:43-8.

15. Solberg HE. Using a hospitalized population to establish reference intervals: pros and cons. Clin Chem 1994;40:2205-6.

16. Grossi E, Colombo R, Cavuto S, Franzini C. The REALAB project: a new method for the formulation of reference intervals based on current data. Clin Chem 2005;51:1232-40.

17. Kouri T, Kairisto V, Virtanen A, Uusipaikka E, Rajamaki A, Finneman $\mathrm{H}$, et al. Reference intervals developed from data for hospitalized patients: computerized method based on combination of laboratory and diagnostic data. Clin Chem 1994;40:2209-15.

18. $\mathrm{R}$ Development Core Team. $\mathrm{R}$ : a language and environment for statistical computing. Vienna: R Foundation for Statistical Computing, 2010.

19. Ceriotti F, Hinzmann R, Panteghini M. Reference intervals: the way forward. Ann Clin Biochem 2009;46:8-17.

20. Richtlinie der Bundesärztekammer zur Qualitätssicherung laboratoriumsmedizinischer Untersuchungen. Dt Ärzteblatt 2008;105:A341-55.

21. Arceci R, Hann IM, Smith OP. Pediatric hematology. Malden, MA: Blackwell Publishing, 2006.

22. Orkin SH, Nathan DG. Nathan and Oski's hematology of infancy and childhood, 7th ed. Philadelphia: Saunders/Elsevier, 2009.

23. Irwin JJ, Kirchner JT. Anemia in children. Am Fam Physician 2001;64:1379-86.

24. Saarinen UM, Siimes MA. Developmental changes in red blood cell counts and indices of infants after exclusion of iron deficiency by laboratory criteria and continuous iron supplementation. J Pediatr 1978;92:412-6.

25. Virtanen A, Kairisto V, Uusipaikka E. Regression-based reference limits: determination of sufficient sample size.

Clin Chem 1998;44:2353-8. 


\section{Literaturverzeichnis}

1. Ceriotti, F., Establishing pediatric reference intervals: a challenging task. Clin Chem, 2012.

2. Solberg, H.E., A guide to IFCC recommendations on reference values. J Int Fed Clin Chem, 1993.

3. Jones, G., A. Barker, Reference intervals. Clin Biochem Rev, 2008.

4. Defining, Establishing, and Verifying Reference Intervals in the Clinical Laboratory; Approved Guideline-Third Edition. 2008, Clinical and Laboratory Standards Institute: Wayne, PA, USA.

5. Pediatric reference intervals: critical gap analysis and establishment of a national initiative. Clin Biochem, 2006.

6. Jung, B., K. Adeli, Clinical laboratory reference intervals in pediatrics: the CALIPER initiative. Clin Biochem, 2009.

7. Kulasingam, V., B.P. Jung, I.M. Blasutig, S. Baradaran, M.K. Chan, M. Aytekin, D.A. Colantonio, K. Adeli, Pediatric reference intervals for 28 chemistries and immunoassays on the Roche cobas 6000 analyzer--a CALIPER pilot study. Clin Biochem, 2010.

8. Colantonio, D.A., L. Kyriakopoulou, M.K. Chan, C.H. Daly, D. Brinc, A.A. Venner, M.D. Pasic, D. Armbruster, K. Adeli, Closing the gaps in pediatric laboratory reference intervals: a CALIPER database of 40 biochemical markers in a healthy and multiethnic population of children. Clin Chem, 2012.

9. Dortschy, R., A.S. Rosario, C. Scheidt-Nave, W. Thierfelder, M. Thamm, J. Gutsche, A. Markert, Bevölkerungsbezogene Verteilungswerte ausgewählter Laborparameter aus der Studie zur Gesundheit von Kindern und Jugendlichen in Deutschland (KiGGS), in Gesundheitsberichterstattung des Bundes. 2009, Robert Koch-Institut: Berlin.

10. Friedberg, R.C., R. Souers, E.A. Wagar, A.K. Stankovic, P.N. Valenstein, The origin of reference intervals. Arch Pathol Lab Med, 2007.

11. Hinzmann, R., Customer Information Paediatric reference intervals on the Sysmex XE-2100 haematological analyser. 2010.

12. Arzideh, F., G. Brandhorst, E. Gurr, W. Hinsch, T. Hoff, L. Roggenbuck, G. Rothe, G. Schumann, B. Wolters, W. Wosniok, R. Haeckel, An improved indirect approach for determining reference limits from intra-laboratory data bases exemplified by concentrations of electrolytes. LaboratoriumsmedizinJournal of Laboratory Medicine, 2009.

13. Arzideh, F., W. Wosniok, R. Haeckel, Reference limits of plasma and serum creatinine concentrations from intra-laboratory data bases of several German and Italian medical centres: Comparison between direct and indirect procedures. Clin Chim Acta, 2010.

14. Concordet, D., A. Geffre, J.P. Braun, C. Trumel, A new approach for the determination of reference intervals from hospital-based data. Clin Chim Acta, 2009.

15. Solberg, H.E., Using a hospitalized population to establish reference intervals: pros and cons. Clin Chem, 1994.

16. Grossi, E., R. Colombo, S. Cavuto, C. Franzini, The REALAB project: a new method for the formulation of reference intervals based on current data. Clin Chem, 2005.

17. Kouri, T., V. Kairisto, A. Virtanen, E. Uusipaikka, A. Rajamaki, H. Finneman, K. Juva, T. Koivula, V. Nanto, Reference intervals developed from data for hospitalized patients: computerized method based on combination of laboratory and diagnostic data. Clin Chem, 1994.

18. R Development Core Team, R: A Language and Environment for Statistical ComputingAuflage. R Foundation for Statistical Computing. Vienna, 2010.

19. Ceriotti, F., R. Hinzmann, M. Panteghini, Reference intervals: the way forward. Ann Clin Biochem, 2009. 
20. Richtlinie der Bundesärztekammer zur Qualitätssicherung laboratoriumsmedizinischer Untersuchungen. Deutsches Ärzteblatt, 2008.

21. Arceci, R., Hann, Ian M., Smith, Owen P., Pediatric hematology. 3. Auflage. Blackwell Pub. Malden, MA, 2006.

22. Orkin, S.H., Nathan, David G., Nathan and Oski's hematology of infancy and childhood. 7. Auflage. Saunders/Elsevier. Philadelphia, 2009.

23. Irwin, J.J., J.T. Kirchner, Anemia in children. Am Fam Physician, 2001.

24. Saarinen, U.M., M.A. Siimes, Developmental changes in red blood cell counts and indices of infants after exclusion of iron deficiency by laboratory criteria and continuous iron supplementation. J Pediatr, 1978.

25. Virtanen, A., V. Kairisto, E. Uusipaikka, Regression-based reference limits: determination of sufficient sample size. Clin Chem, 1998.

26. Soldin, S.J., C. Brugnara, E.C. Wong, Pediatric reference ranges. 4. Auflage. AACC Press. Washington, DC, 2003. 248. 


\section{Abkürzungsverzeichnis}

\begin{tabular}{|c|c|}
\hline RI, -s & Referenzintervall, -e \\
\hline CALIPER & Canadian Laboratory Initiative on PEdiatric Reference Intervals \\
\hline KiGGS & $\begin{array}{l}\text { Studie zur Gesundheit von Kindern und Jugendlichen in } \\
\text { Deutschland } \\
\text { German Health Interview and Examination Survey for Children } \\
\text { and Adolescents }\end{array}$ \\
\hline IFCC & $\begin{array}{l}\text { International Federation of Clinical Chemistry and Laboratory } \\
\text { Medicine }\end{array}$ \\
\hline MCV & $\begin{array}{l}\text { Mittleres Erythrozyteneinzelvolumen } \\
\text { Mean red cell volume }\end{array}$ \\
\hline $\mathrm{MCH}$ & $\begin{array}{l}\text { Mittleres korpuskuläres Hämoglobin des Einzelerythrozyten } \\
\text { Mean red cell hemoglobin }\end{array}$ \\
\hline $\mathrm{MCHC}$ & $\begin{array}{l}\text { Mittlere Hämoglobinkonzentration des Einzelerythrozyten } \\
\text { Mean red cell hemoglobin concentration }\end{array}$ \\
\hline RDWCV & $\begin{array}{l}\text { Erythrozytenverteilungsbreite } \\
\text { Red cell distribution width coefficient of variation }\end{array}$ \\
\hline iRI & Indirekte Referenzintervalle \\
\hline
\end{tabular}




\section{Supplemental data}

\begin{tabular}{lrrrrr} 
Quantity & \multicolumn{2}{r}{ No. of samples } & & \multicolumn{2}{c}{ No. of time frames } \\
\cline { 2 - 3 } & Total & w/o ICU, ONC & & Total & w/o ICU, ONC \\
\hline Hemoglobin & 58,065 & 42,845 & & 127 & 117 \\
MCV & 58,070 & 42,847 & & 127 & 117 \\
MCH & 58,067 & 42,844 & & 127 & 117 \\
MCHC & 58,066 & 42,844 & & 127 & 117 \\
Platelets & 58,040 & 42,836 & & 127 & 117 \\
Red blood cells & 58,071 & 42,848 & 127 & 117 \\
Hematocrit & 58,069 & 42,846 & 127 & 117 \\
RDWCV & 56,253 & 41,517 & & 122 & 114 \\
Plasma sodium & 60,394 & 45,126 & & 125 & 114 \\
\hline
\end{tabular}

Supplemental Table 1 Quantities for which RIs were calculated. Sample counts differ since not all measurements could be performed on all blood samples, RDWCV measurement was not performed until 02/2008.

$\mathrm{ICU}$, intensive care unit; $\mathrm{MCH}$, mean red cell hemoglobin; $\mathrm{MCHC}$, mean red cell hemoglobin concentration; MCV, mean red cell volume; ONC, oncological unit; RDWCV, red cell distribution width variation coefficient.

\begin{tabular}{|c|c|c|c|c|c|c|c|c|c|c|}
\hline & $\begin{array}{r}\text { Control } \\
\text { sample target } \\
\text { value (low) }\end{array}$ & $\begin{array}{r}\text { Inaccuracy, } \\
\text { bias }\end{array}$ & $\begin{array}{r}\text { Imprecision, } \\
\text { CV }\end{array}$ & QMMA & $\mathrm{n}$ & $\begin{array}{r}\text { Control } \\
\text { sample target } \\
\text { value (high) }\end{array}$ & $\begin{array}{r}\text { Inaccuracy, } \\
\text { bias }\end{array}$ & $\begin{array}{r}\text { Imprecision, } \\
\text { CV }\end{array}$ & QMMA & \\
\hline Hemoglobin & $5.6 \mathrm{~g} / \mathrm{dL}$ & $0.3 \%$ & $0.70 \%$ & $0.75 \%$ & 34 & $12.3 \mathrm{~g} / \mathrm{dL}$ & $0.0 \%$ & $0.47 \%$ & $0.46 \%$ & 32 \\
\hline MCV & $74.2 \mathrm{fL}$ & $1.1 \%$ & $0.49 \%$ & $0.85 \%$ & 34 & $80.8 \mathrm{fL}$ & $1.5 \%$ & $0.41 \%$ & $1.28 \%$ & 32 \\
\hline $\mathrm{MCH}$ & $24.5 \mathrm{pg}$ & $1.7 \%$ & $1.09 \%$ & $0.48 \%$ & 34 & $27.8 \mathrm{pg}$ & $1.2 \%$ & $0.57 \%$ & $0.36 \%$ & 32 \\
\hline $\mathrm{MCHC}$ & $32.9 \mathrm{~g} / \mathrm{dL}$ & $0.2 \%$ & $1.07 \%$ & $0.35 \%$ & 34 & $34.5 \mathrm{~g} / \mathrm{dL}$ & $0.1 \%$ & $0.74 \%$ & $0.25 \%$ & 32 \\
\hline Platelets & $52 \times 10^{3} / \mu \mathrm{L}$ & $0.2 \%$ & $3.53 \%$ & $3.44 \%$ & 34 & $204 \times 10^{3} / \mu \mathrm{L}$ & $1.0 \%$ & $1.42 \%$ & $2.15 \%$ & 32 \\
\hline Red blood cells & $2.29 \times 10^{6} / \mu \mathrm{L}$ & $1.8 \%$ & $0.71 \%$ & $1.90 \%$ & 34 & $4.42 \times 10^{6} / \mu \mathrm{L}$ & $1.3 \%$ & $0.48 \%$ & $1.38 \%$ & 32 \\
\hline Hematocrit & $17 \%$ & $0.6 \%$ & $0.79 \%$ & $1.01 \%$ & 34 & $35.7 \%$ & $0.2 \%$ & $0.66 \%$ & $0.68 \%$ & 32 \\
\hline Plasma sodium & $115 \mathrm{mmol} / \mathrm{L}$ & $0.0 \%$ & $0.99 \%$ & $1.44 \%$ & 36 & $140 \mathrm{mmol} / \mathrm{L}$ & $0.0 \%$ & $0.59 \%$ & $0.80 \%$ & 33 \\
\hline
\end{tabular}

Supplemental Table 2 Measurement accuracy and precision data.

Accuracy and precision data for selected quantities in a single month. The results of measurements of control samples (with defined target values) as part of our routine quality control are shown. QMMA denotes quadratic mean of error of measurement and is a measurement of both accuracy and precision, it is defined as follows: $Q M M A=\sqrt{\frac{1}{n} \sum_{i=1}^{n}\left(x_{i}-x_{0}\right)^{2}}\left(x_{i}-\right.$ sample value; $x_{0}-$ target value).

$\mathrm{CV}$, coefficient of variation; $\mathrm{MCH}$, mean red cell hemoglobin; $\mathrm{MCHC}$, mean red cell hemoglobin concentration; MCV, mean red cell volume; RDWCV, red cell distribution width variation coefficient. 


\begin{tabular}{|c|c|c|c|c|c|c|c|c|c|}
\hline Month & $\begin{array}{r}\text { Hemoglobin, } \\
\mathrm{g} / \mathrm{dL}\end{array}$ & $\begin{array}{r}\mathrm{MCV}, \\
\mathrm{fL}\end{array}$ & $\begin{array}{r}\text { MCH, } \\
\text { pg }\end{array}$ & $\begin{array}{r}\text { MCHC, } \\
\text { g/dL }\end{array}$ & $\begin{array}{l}\text { Platelets, } \\
1000 / \mu \mathrm{L}\end{array}$ & $\begin{array}{r}\text { Red blood } \\
\text { cells, } 10^{6} / \mu \mathrm{L}\end{array}$ & Hematocrit, \% & $\begin{array}{r}\text { RDWCV, } \\
\text { CV }\end{array}$ & $\begin{array}{r}\text { Plasma sodium, } \\
\mathrm{mmol} / \mathrm{L}\end{array}$ \\
\hline $2008 / 01$ & 12.5 & 87 & 29 & 33 & 262 & 4.41 & 38.0 & 14.3 & 136 \\
\hline $2008 / 02$ & 12.3 & 86 & 29 & 33 & 256 & 4.36 & 37.4 & 14.4 & 136 \\
\hline $2008 / 03$ & 12.3 & 86 & 29 & 33 & 251 & 4.34 & 37.5 & 14.5 & 136 \\
\hline $2008 / 04$ & 12.5 & 87 & 29 & 33 & 252 & 4.37 & 37.9 & 14.6 & 136 \\
\hline $2008 / 05$ & 12.6 & 87 & 29 & 33 & 251 & 4.36 & 37.9 & 14.6 & 136 \\
\hline $2008 / 06$ & 12.4 & 85 & 29 & 34 & 257 & 4.34 & 37.2 & 14.1 & 136 \\
\hline $2008 / 07$ & 12.3 & 85 & 29 & 34 & 240 & 4.34 & 36.6 & 13.8 & 136 \\
\hline $2008 / 08$ & 12.2 & 86 & 29 & 34 & 253 & 4.28 & 36.6 & 13.8 & 136 \\
\hline $2008 / 09$ & 12.8 & 87 & 29 & 34 & 254 & 4.43 & 38.2 & 14.1 & 136 \\
\hline $2008 / 10$ & 12.4 & 87 & 29 & 33 & 265 & 4.36 & 37.4 & 14.2 & 136 \\
\hline $2008 / 11$ & 12.4 & 87 & 29 & 33 & 260 & 4.39 & 37.9 & 14.2 & 136 \\
\hline $2008 / 12$ & 12.5 & 87 & 29 & 33 & 256 & 4.43 & 38.0 & 14.4 & 136 \\
\hline $2009 / 01$ & 12.5 & 87 & 29 & 33 & 251 & 4.42 & 38.2 & 14.3 & 137 \\
\hline $2009 / 02$ & 12.3 & 86 & 28 & 33 & 259 & 4.37 & 37.7 & 14.2 & 136 \\
\hline $2009 / 03$ & 12.3 & 87 & 29 & 33 & 254 & 4.35 & 37.3 & 14.7 & 136 \\
\hline $2009 / 04$ & 12.2 & 86 & 29 & 33 & 256 & 4.32 & 37.0 & 14.4 & 136 \\
\hline $2009 / 05$ & 12.3 & 87 & 29 & 33 & 247 & 4.32 & 37.6 & 14.3 & 136 \\
\hline $2009 / 06$ & 12.4 & 86 & 29 & 33 & 241 & 4.36 & 37.7 & 14.2 & 136 \\
\hline $2009 / 07$ & 12.3 & 86 & 29 & 34 & 247 & 4.40 & 37.0 & 14.2 & 135 \\
\hline $2009 / 08$ & 12.3 & 85 & 29 & 34 & 248 & 4.36 & 36.7 & 14.5 & 136 \\
\hline 2009/09 & 12.4 & 86 & 29 & 33 & 243 & 4.38 & 37.4 & 14.3 & 137 \\
\hline $2009 / 10$ & 12.4 & 87 & 29 & 33 & 255 & 4.41 & 38.0 & 14.2 & 137 \\
\hline $2009 / 11$ & 12.3 & 87 & 29 & 33 & 249 & 4.40 & 37.8 & 14.2 & 137 \\
\hline $2009 / 12$ & 12.2 & 87 & 28 & 33 & 254 & 4.34 & 37.3 & 14.2 & 137 \\
\hline $2010 / 01$ & 12.3 & 87 & 29 & 33 & 248 & 4.38 & 37.8 & 14.5 & 137 \\
\hline $2010 / 02$ & 12.6 & 86 & 28 & 33 & 253 & 4.45 & 38.5 & 14.2 & 137 \\
\hline $2010 / 03$ & 12.6 & 87 & 29 & 33 & 249 & 4.45 & 38.5 & 14.4 & 137 \\
\hline $2010 / 04$ & 12.5 & 87 & 29 & 33 & 243 & 4.43 & 38.3 & 14.6 & 137 \\
\hline $2010 / 05$ & 12.6 & 87 & 29 & 33 & 237 & 4.46 & 38.7 & 14.7 & 137 \\
\hline
\end{tabular}

Supplemental Table 3 Median values of quantities over time.

Monthly median values for all quantities examined. $\mathrm{MCH}$, mean red cell hemoglobin; $\mathrm{MCHC}$, mean red cell hemoglobin concentration; MCV, mean red cell volume; RDWCV, red cell distribution width variation coefficient.

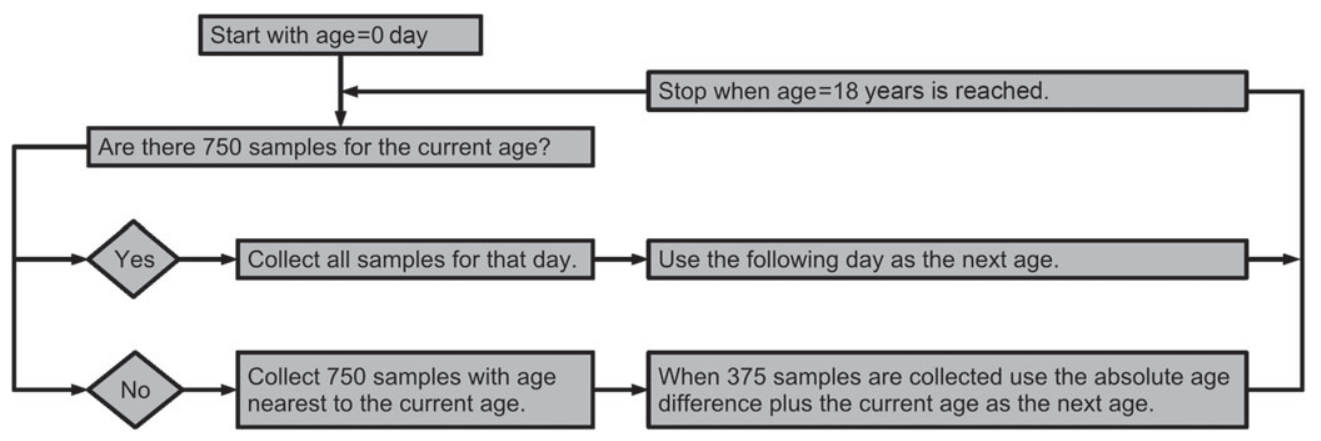

Supplemental Figure 1 Timeline generation algorithm. 
A
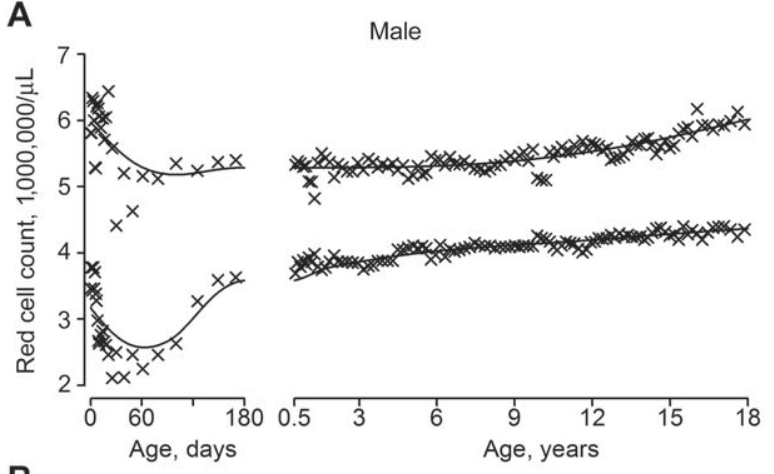

B
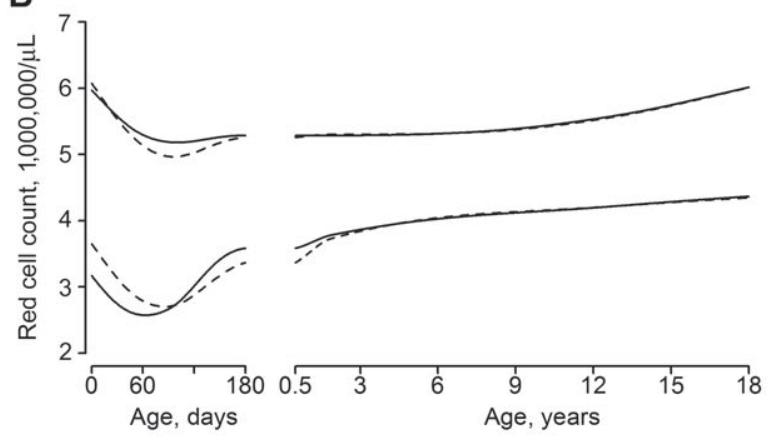

C
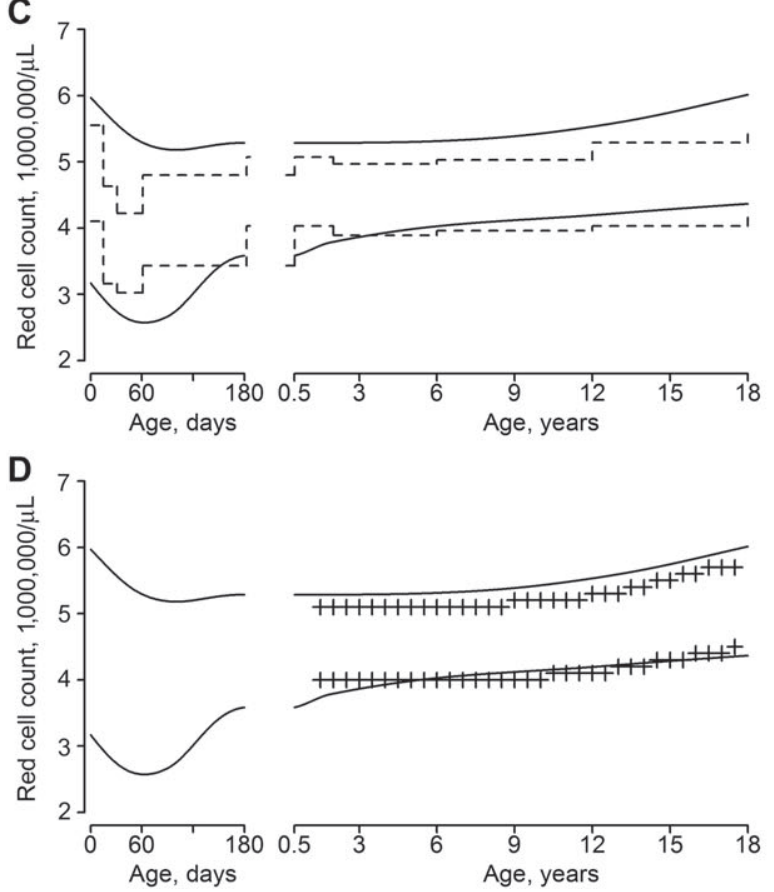

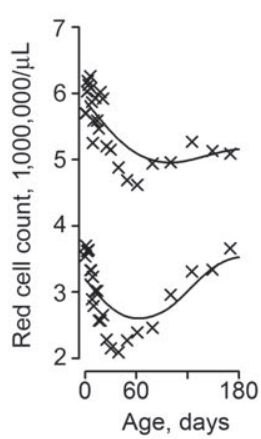

Female
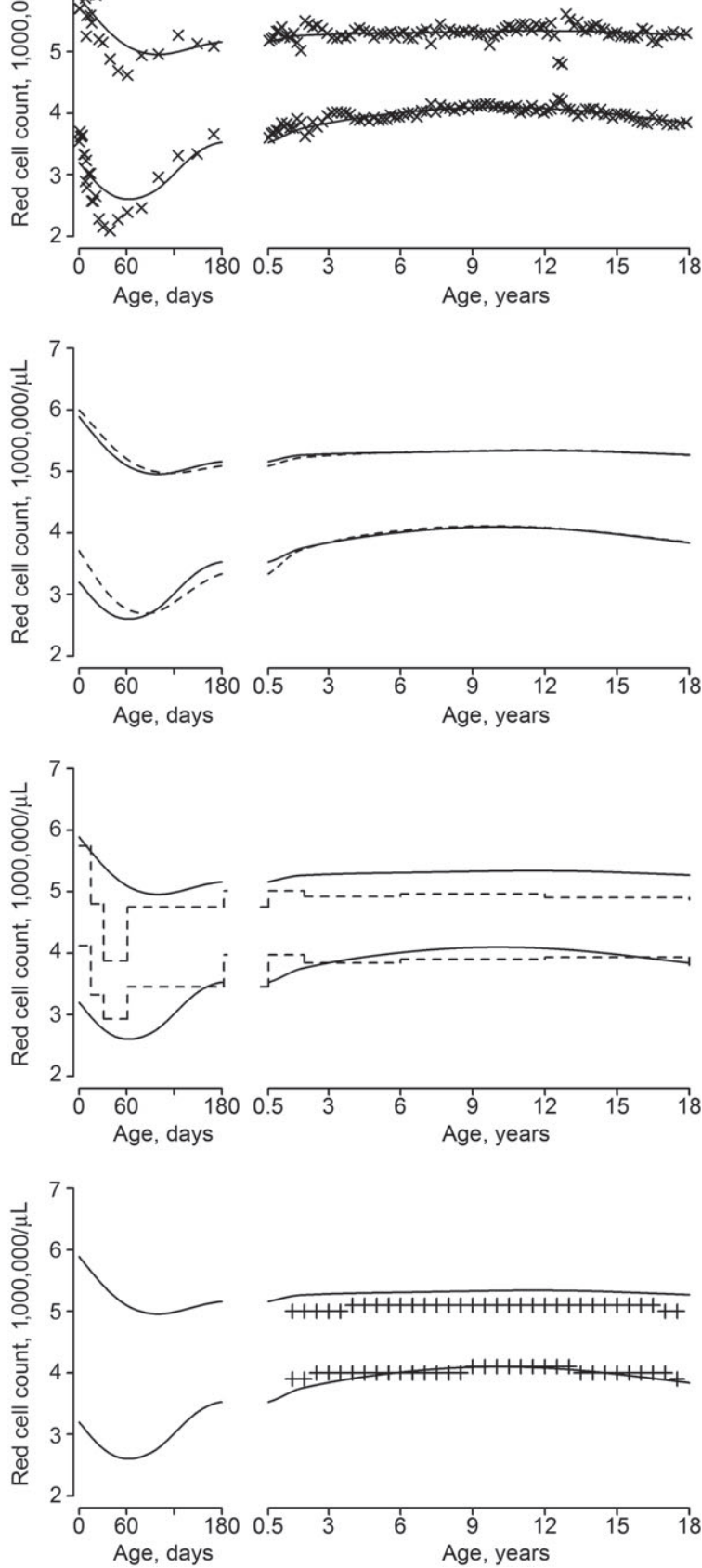

Supplemental Figure 2 Calculation of red cell count RIs.

(A) Fitting a continuous spline (continuous line) to the discrete red cell count RIs (crosses). (B) Comparison of calculated red cell count RIs. (Continuous line=All samples. Dashed black line=Samples from intensive care units/oncological units removed). (C) Calculated Red cell count RIs (continuous line) versus RIs provided by the manufacturer (dashed line) [11]. (D) Calculated red cell count RIs (continuous line) versus RIs determined in the KiGGS study (crosses) [9].

KiGGS, German Health Interview and Examination Survey for Children and Adolescents. 

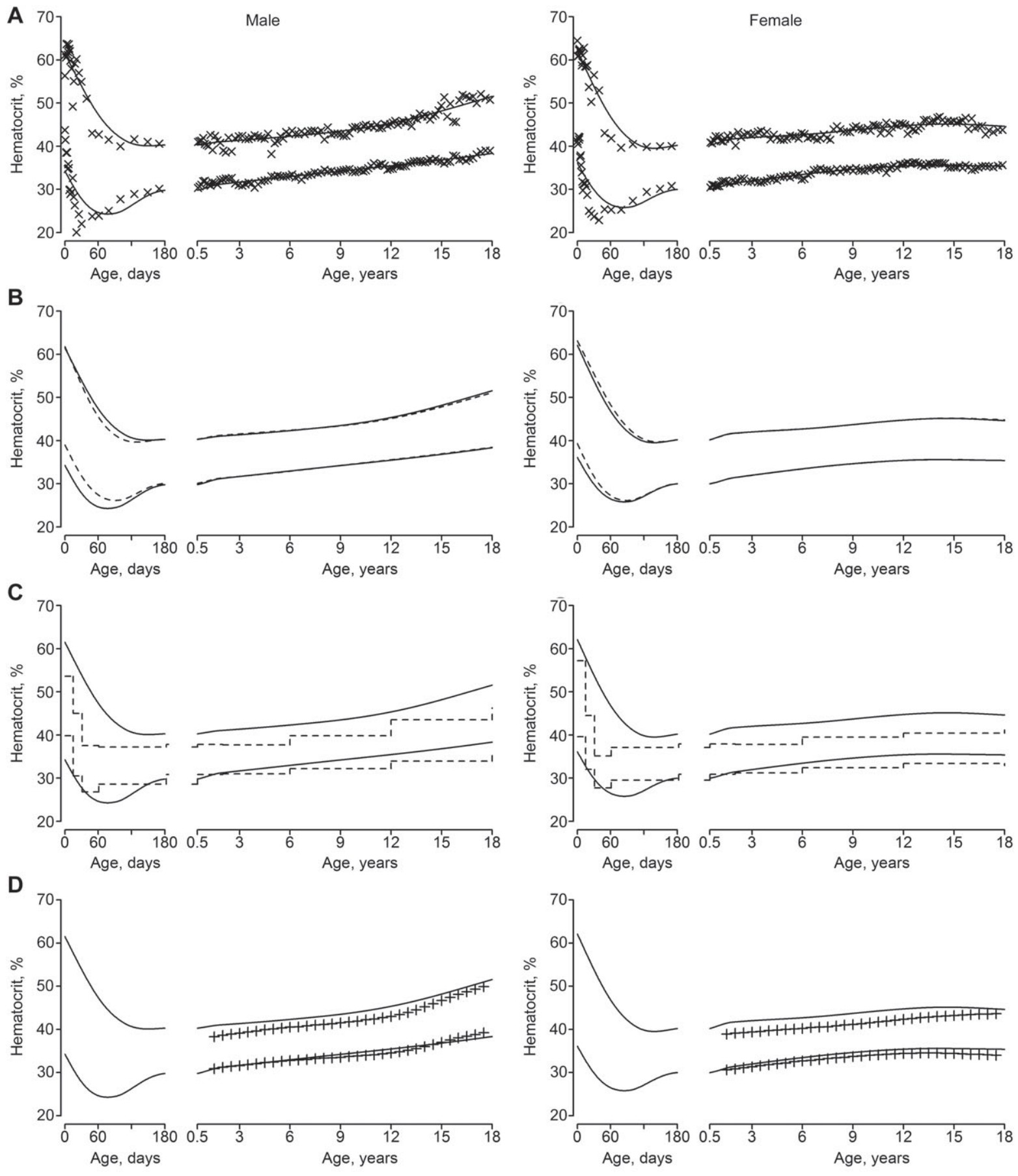

Supplemental Figure 3 Calculation of hematocrit RIs.

(A) Fitting a continuous spline (continuous line) to the discrete hematocrit RIs (crosses). (B) Comparison of calculated hematocrit RIs. (Continuous line=All samples. Dashed black line=Samples from intensive care units/oncological units removed). (C) Calculated hematocrit RIs (continuous line) versus RIs provided by the manufacturer (dashed line) [11]. (D) Calculated hematocrit RIs (continuous line) versus RIs determined in the KiGGS study (crosses) [9]. KiGGS, German Health Interview and Examination Survey for Children and Adolescents. 

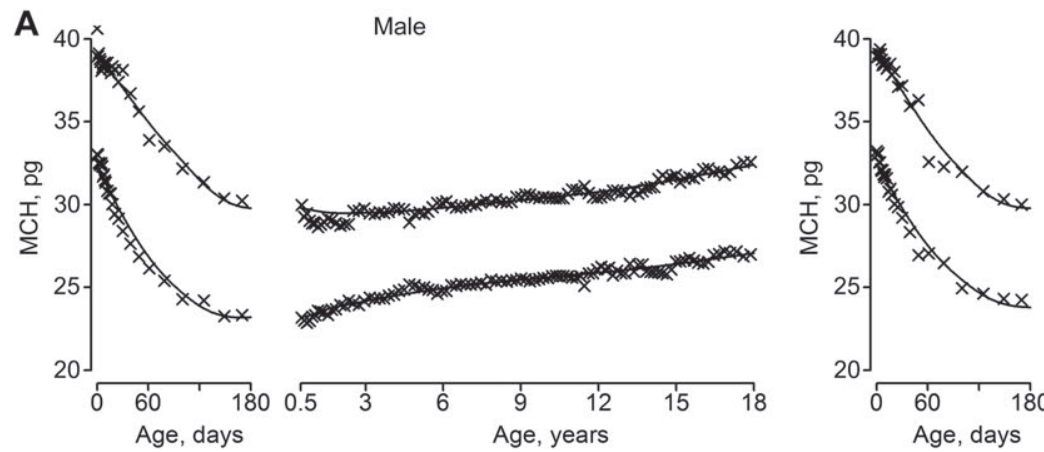

Female

B
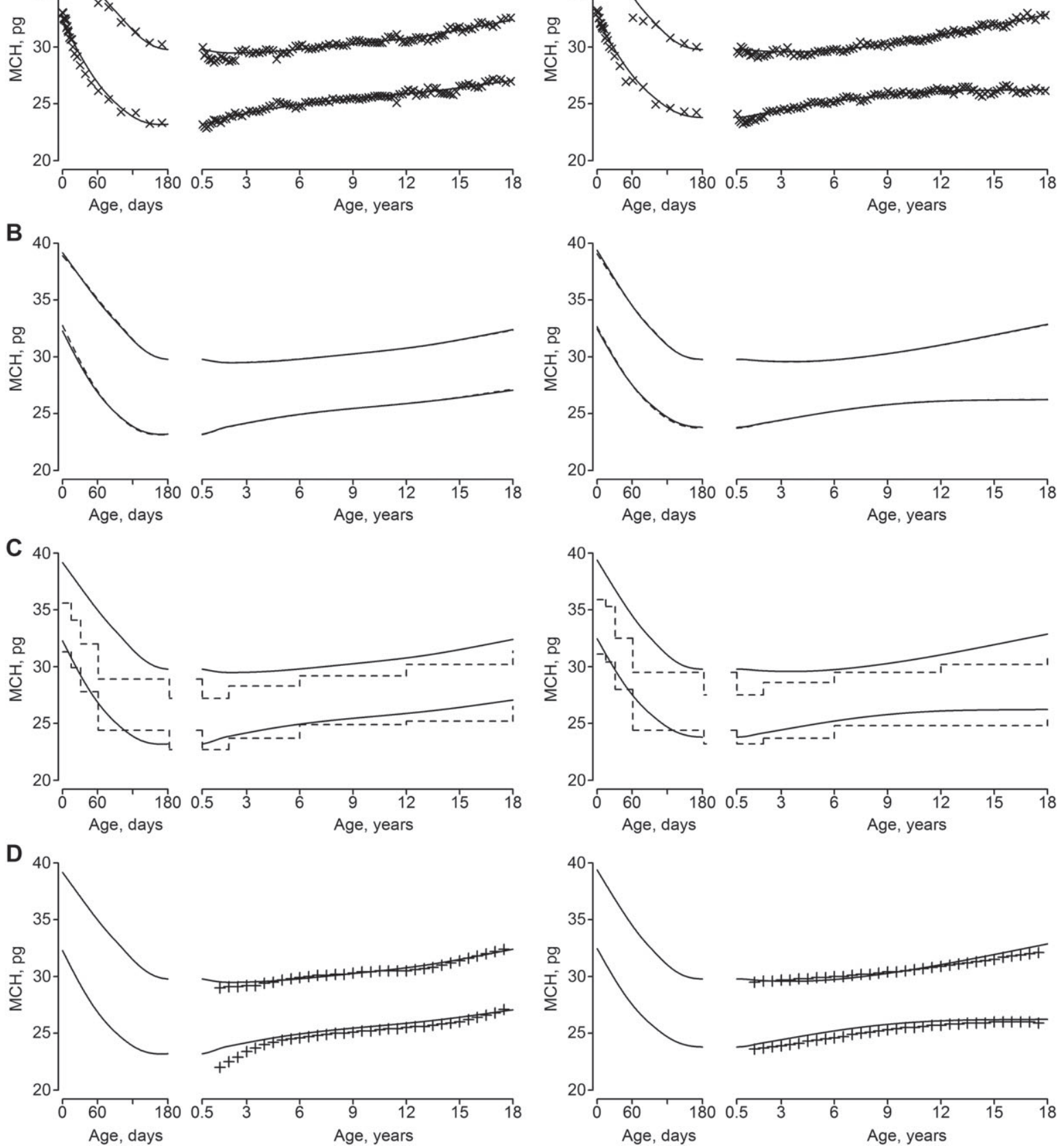

Supplemental Figure 4 Calculation of MCH RIs.

(A) Fitting a continuous spline (continuous line) to the discrete MCH RIs (crosses). (B) Comparison of calculated MCH RIs. (Continuous line=All samples. Dashed black line=Samples from intensive care units/oncological units removed). (C) Calculated MCH RIs (continuous line) versus RIs provided by the manufacturer (dashed line) [11]. (D) Calculated MCH RIs (continuous line) versus RIs determined in the KiGGS study (crosses) [9].

KiGGS, German Health Interview and Examination Survey for Children and Adolescents; MCH, mean red cell hemoglobin. 

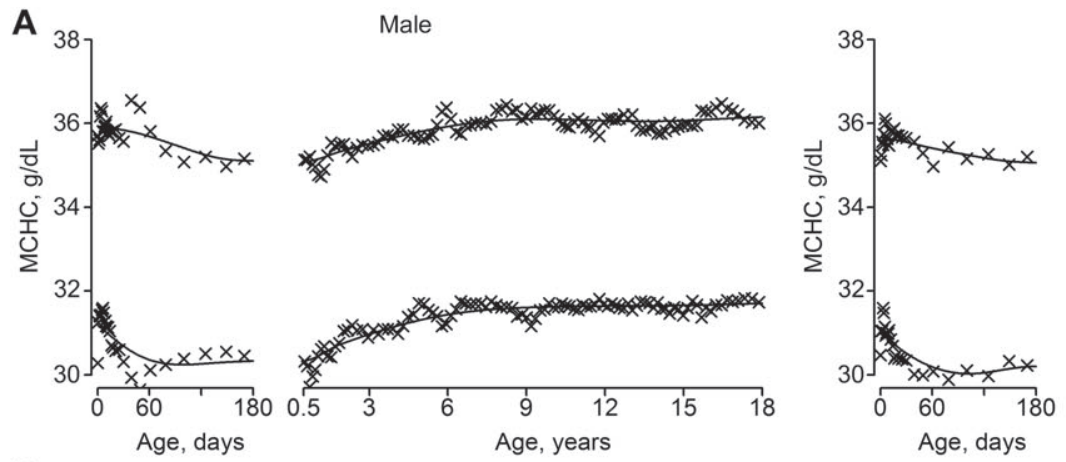

Female
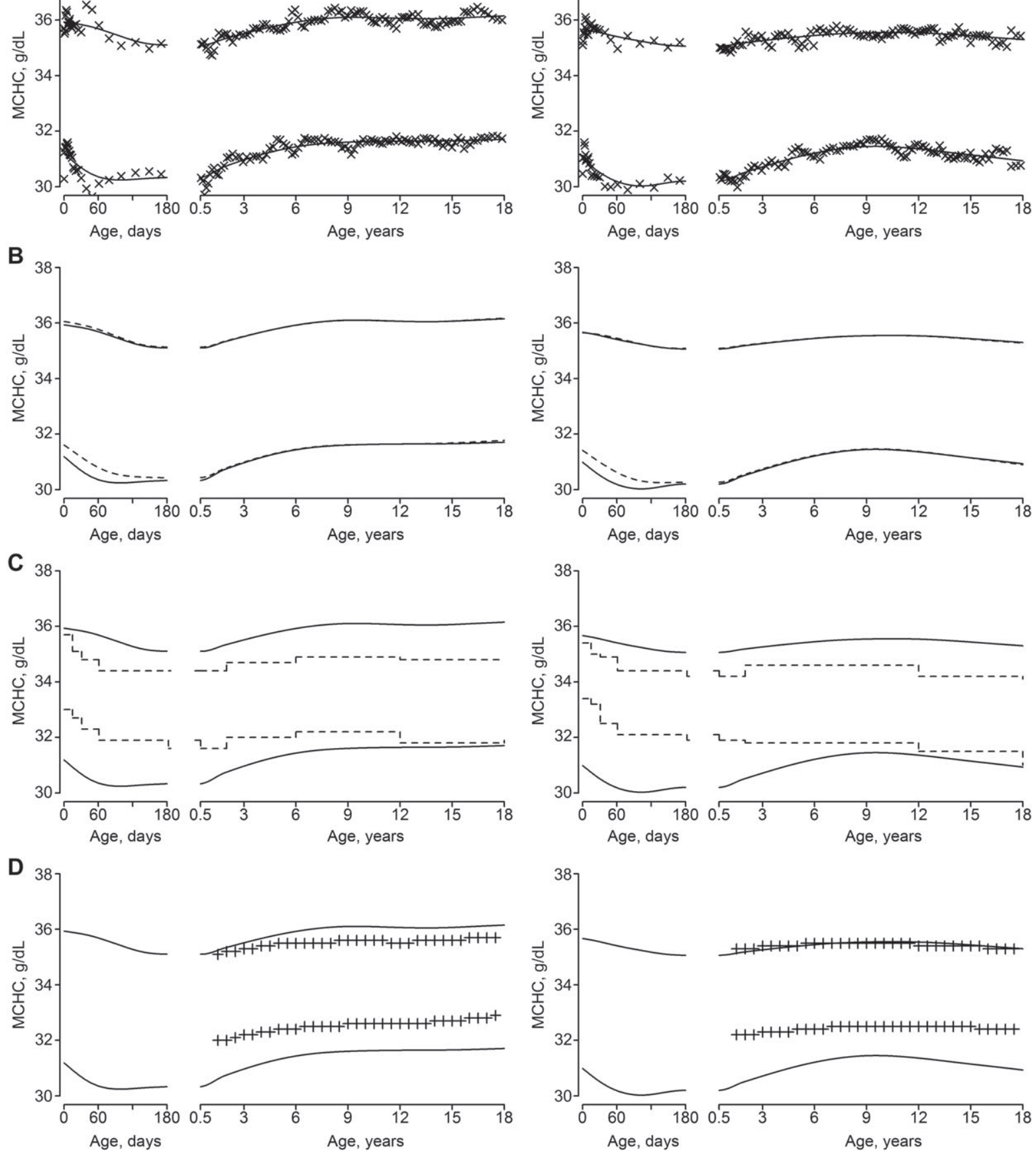

Supplemental Figure 5 Calculation of MCHC RIs.

(A) Fitting a continuous spline (continuous line) to the discrete MCHC RIs (crosses). (B) Comparison of calculated MCHC RIs. (Continuous line=All samples. Dashed black line=Samples from intensive care units/oncological units removed). (C) Calculated MCHC RIs (continuous line) versus RIs provided by the manufacturer (dashed line) [11]. (D) Calculated MCHC RIs (continuous line) versus RIs determined in the KiGGS study (crosses) [9].

KiGGS, German Health Interview and Examination Survey for Children and Adolescents; MCHC, mean red cell hemoglobin concentration. 

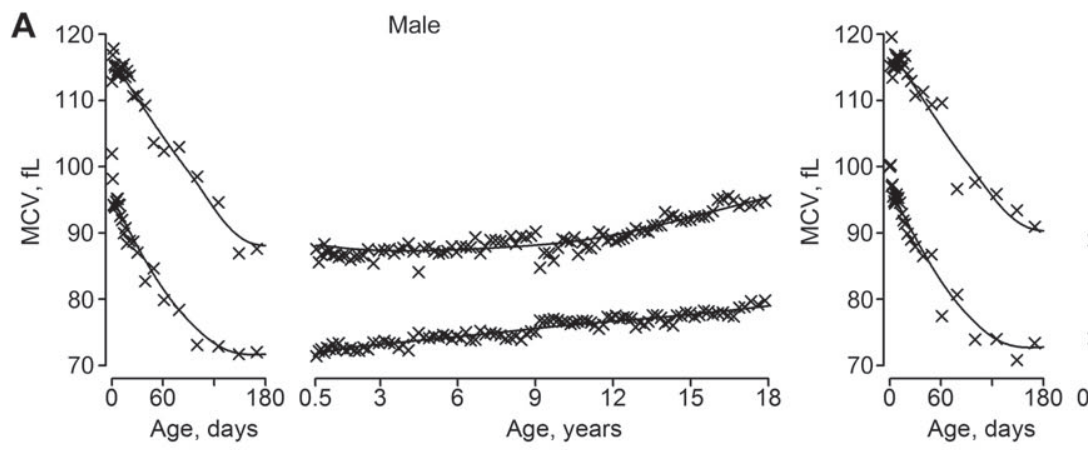

Female

B
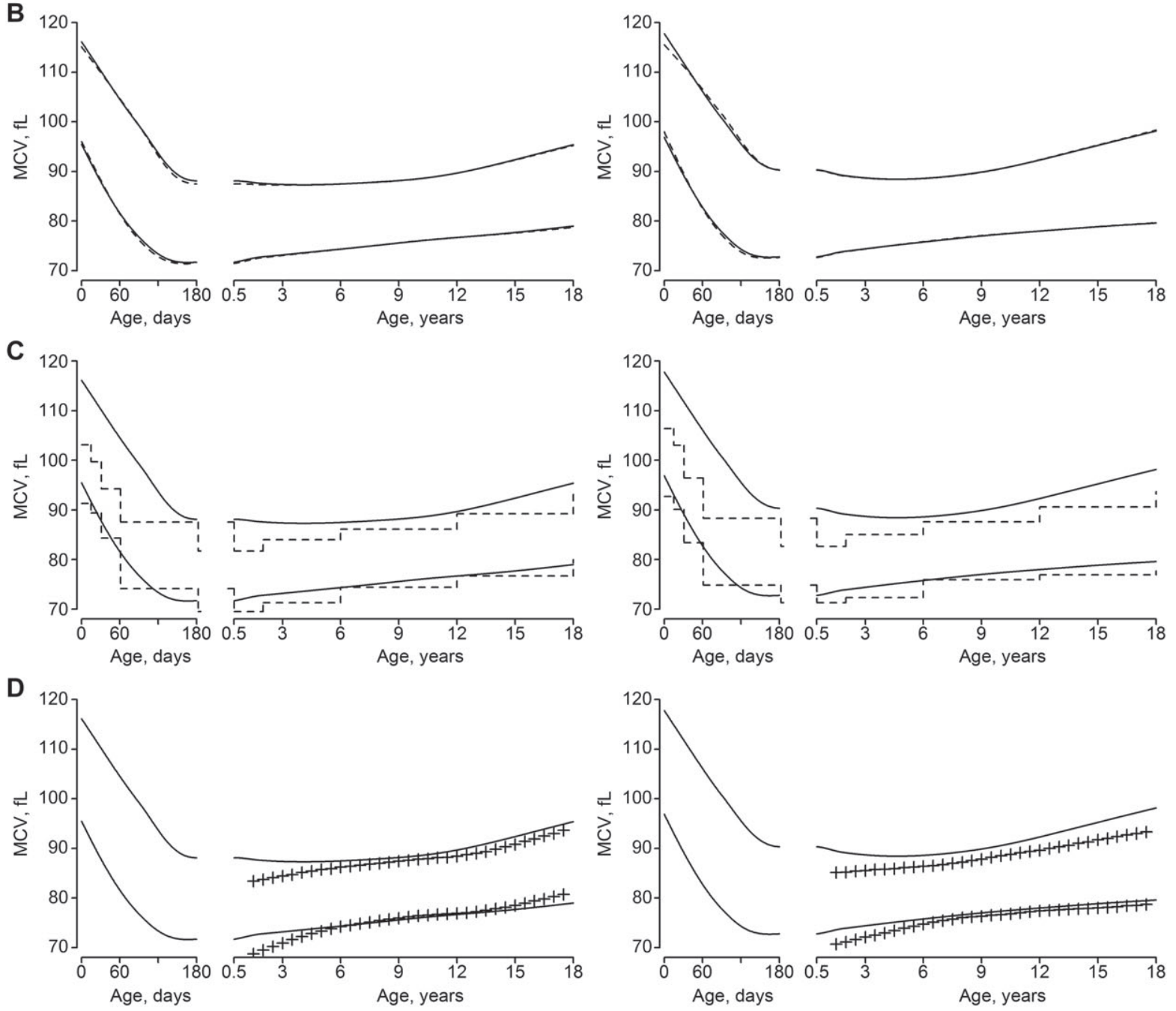

Supplemental Figure 6 Calculation of MCV RIs.

(A) Fitting a continuous spline (continuous line) to the discrete MCV RIs (crosses). (B) Comparison of calculated MCV RIs. (Continuous line=All samples. Dashed black line=Samples from intensive care units/oncological units removed). (C) Calculated MCV RIs (continuous line) versus RIs provided by the manufacturer (dashed line) [11]. (D) Calculated MCV RIs (continuous line) versus RIs determined in the KiGGS study (crosses) [9].

KiGGS, German Health Interview and Examination Survey for Children and Adolescents; MCV, mean red cell volume. 
A

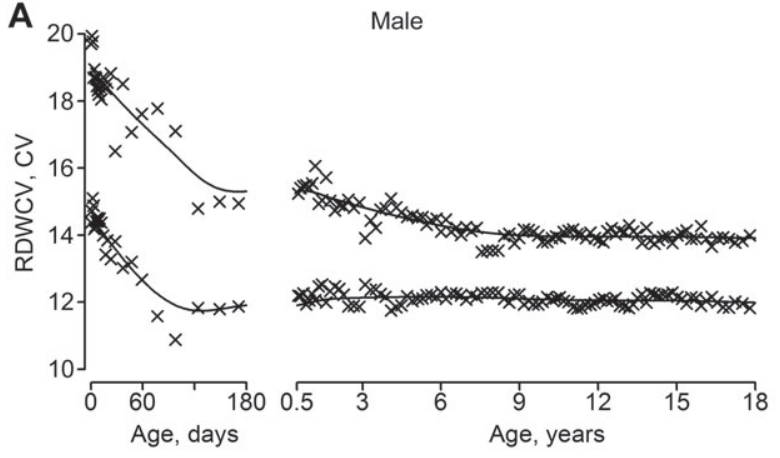

B

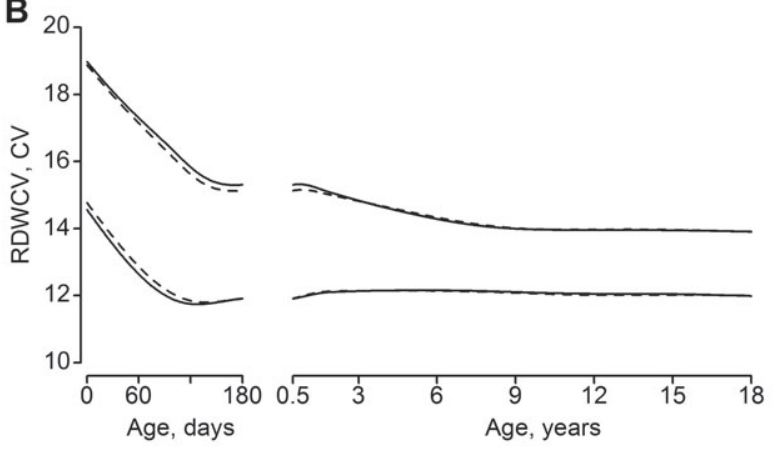

C

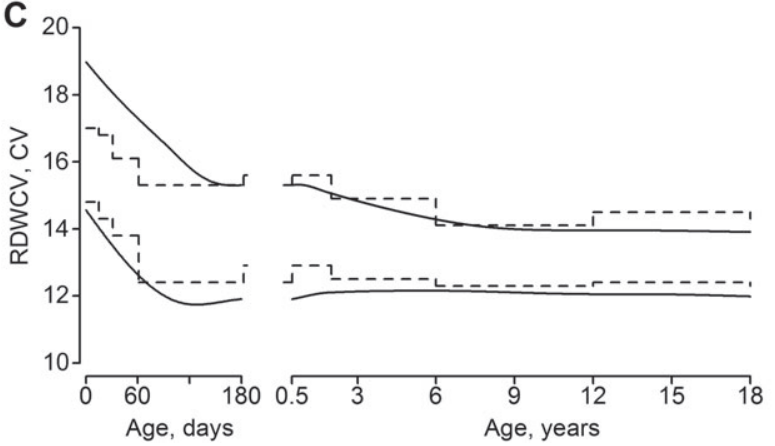

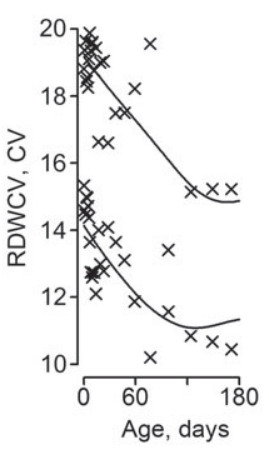

Female
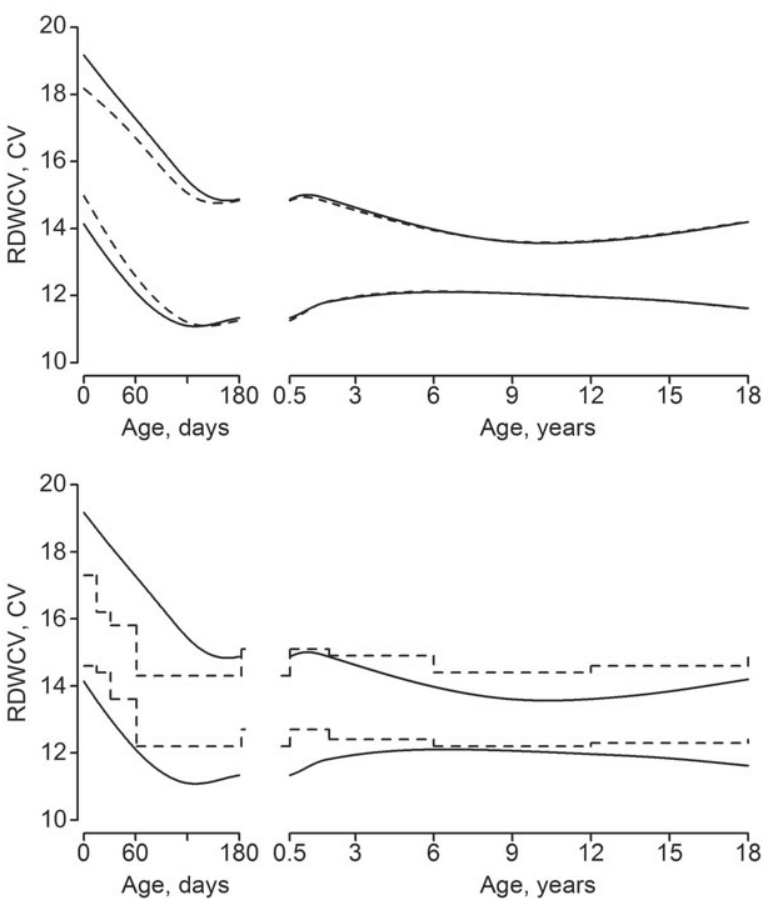

Supplemental Figure 7 Calculation of RDWCV RIs.

(A) Fitting a continuous spline (continuous line) to the discrete RDWCV RIs (crosses). (B) Comparison of calculated RDWCV RIs. (Continuous line=All samples. Dashed black line=Samples from intensive care units/oncological units removed). (C) Calculated RDWCV RIs (continuous line) versus RIs provided by the manufacturer (dashed line) [11].

RDWCV, red cell distribution width variation coefficient. 

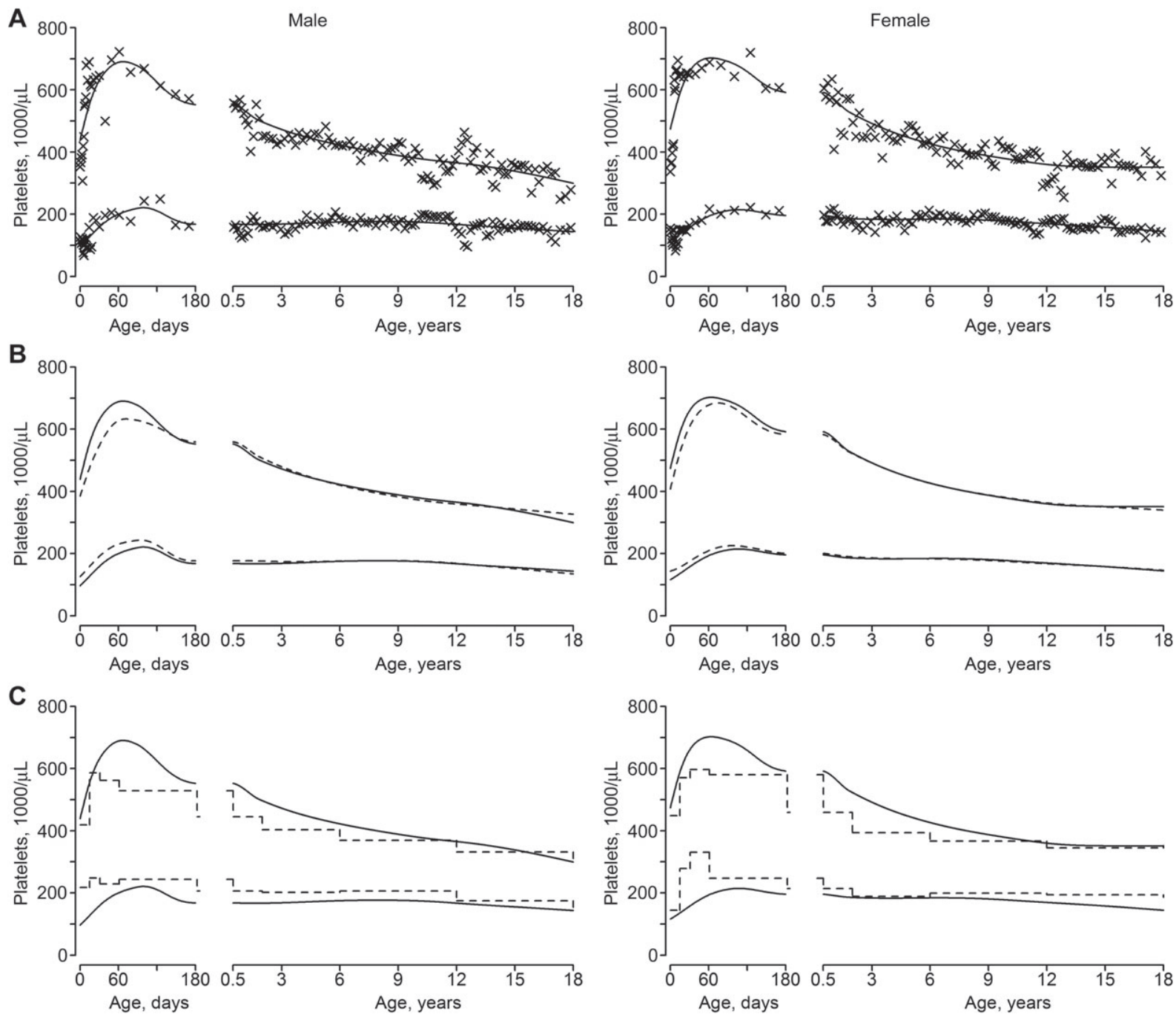

Supplemental Figure 8 Calculation of platelet count RIs.

(A) Fitting a continuous spline (continuous line) to the discrete platelet count RIs (crosses). (B) Comparison of calculated platelet count RIs. (Continuous line=All samples. Dashed black line=Samples from intensive care units/oncological units removed). (C) Calculated platelet count RIs (continuous line) versus RIs provided by the manufacturer (dashed line) [11]. 
A
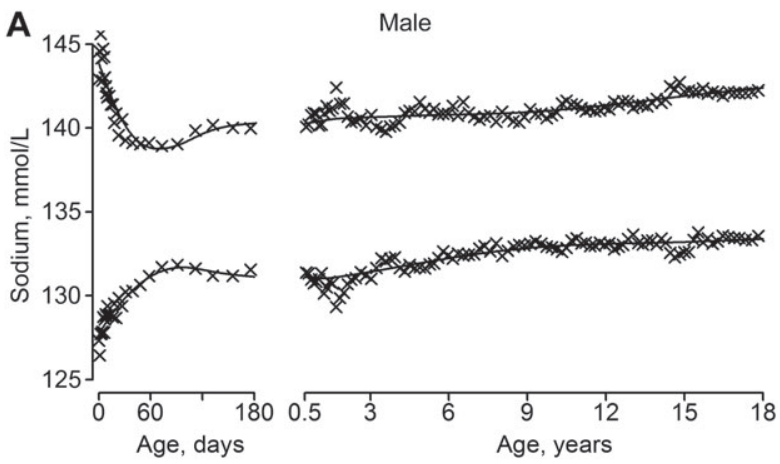

B

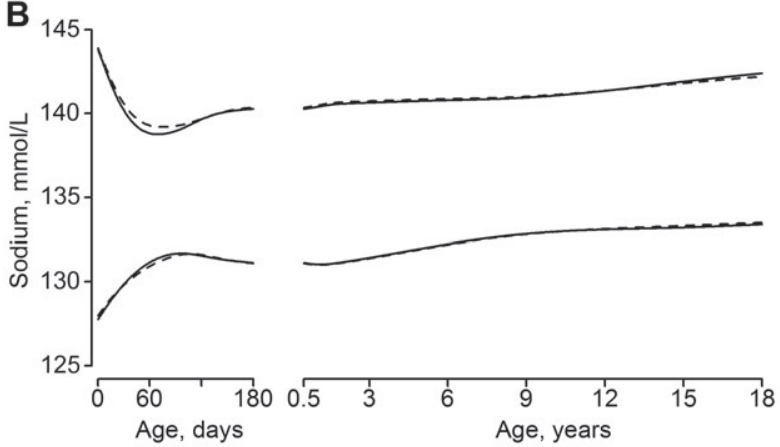

C

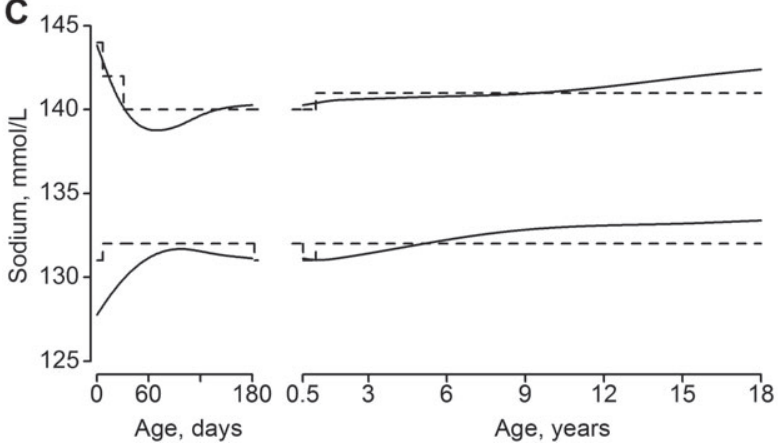

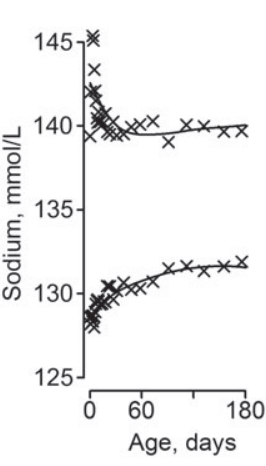

Female
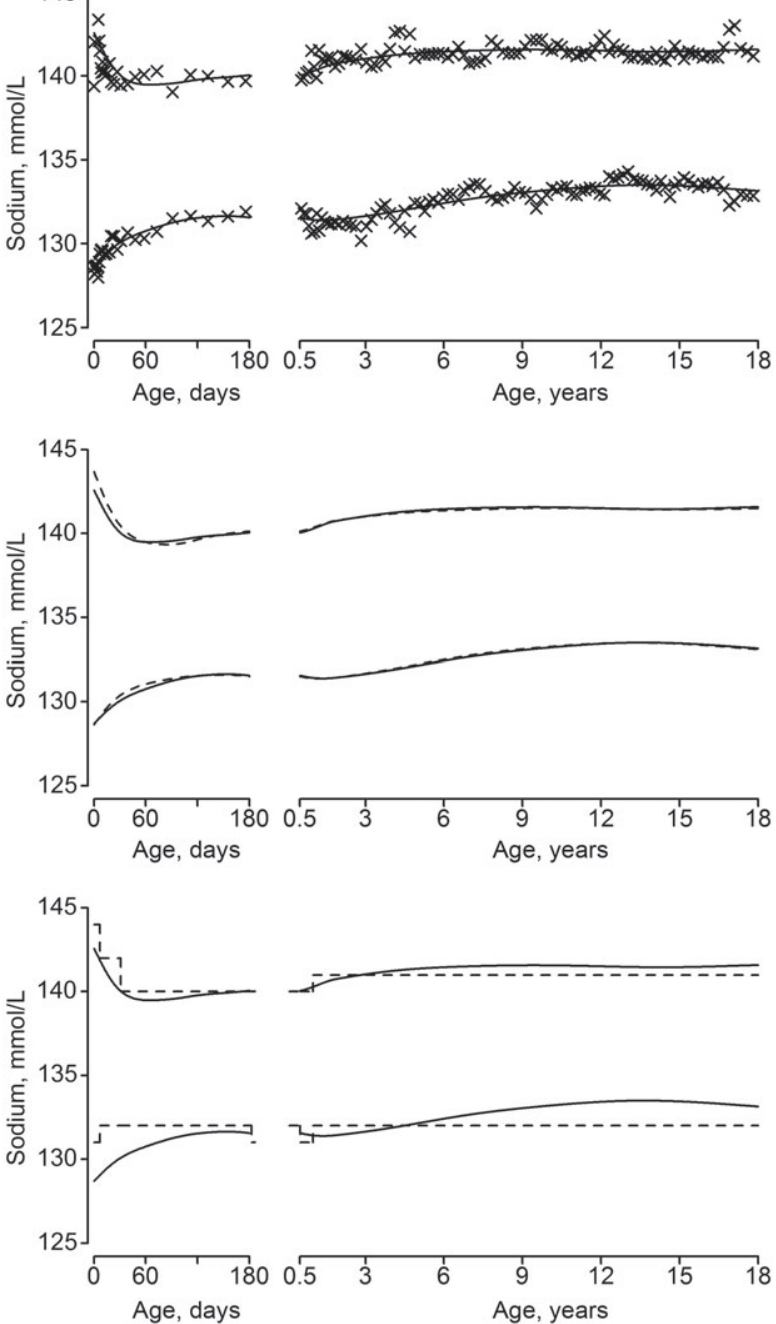

Supplemental Figure 9 Calculation of plasma sodium RIs.

(A) Fitting a continuous spline (continuous line) to the discrete plasma sodium Rls (crosses). (B) Comparison of calculated plasma sodium RIs. (Continuous line=All samples. Dashed black line=Samples from intensive care units/oncological units removed). (C) Calculated plasma sodium RIs (continuous line) versus literature RIs (dashed line) [11]. 
Age

\begin{tabular}{|c|c|c|c|c|c|c|}
\hline \multirow[t]{3}{*}{ Age } & \multicolumn{4}{|c|}{ Hemoglobin, g/dL } & \multirow{2}{*}{\multicolumn{2}{|c|}{ 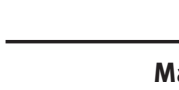 }} \\
\hline & & Male & & Female & & \\
\hline & 2.5th & 97.5th & 2.5th & 97.5th & 2.5th & 97. \\
\hline 0 day & 12.6 & 20.2 & 12.8 & 20.5 & 95 & \\
\hline 1 day & 12.3 & 20.1 & 12.5 & 20.3 & 95 & \\
\hline 2 days & 12.0 & 20.0 & 12.2 & 20.2 & 95 & \\
\hline 3 days & 11.7 & 19.9 & 11.9 & 20.0 & 95 & \\
\hline 4 days & 11.4 & 19.8 & 11.6 & 19.9 & 94 & \\
\hline 5 days & 11.1 & 19.7 & 11.4 & 19.7 & 94 & \\
\hline 6 days & 10.9 & 19.6 & 11.1 & 19.6 & 94 & \\
\hline 1 week & 10.6 & 19.5 & 10.8 & 19.4 & 94 & \\
\hline 2 weeks & 9.2 & 19.3 & 9.4 & 18.8 & 92 & \\
\hline 3 weeks & 8.2 & 18.8 & 8.3 & 18.2 & 90 & \\
\hline 1 month & 7.6 & 17.4 & 7.2 & 17.0 & 88 & \\
\hline 2 months & 7.6 & 14.1 & 7.3 & 13.8 & 81 & \\
\hline 3 months & 8.2 & 13.3 & 8.5 & 13.2 & 76 & \\
\hline 4 months & 9.3 & 13.5 & 9.5 & 13.3 & 73 & \\
\hline 5 months & 9.7 & 13.5 & 9.9 & 13.4 & 72 & \\
\hline 6 months & 9.8 & 13.5 & 9.9 & 13.5 & 72 & \\
\hline 8 months & 9.8 & 13.5 & 9.9 & 13.5 & 72 & \\
\hline 10 months & 9.8 & 13.6 & 9.9 & 13.6 & 72 & \\
\hline 1 year & 9.9 & 13.6 & 10.0 & 13.6 & 72 & \\
\hline 2 years & 10.2 & 13.8 & 10.2 & 13.9 & 73 & \\
\hline 3 years & 10.4 & 13.9 & 10.5 & 14.1 & 73 & \\
\hline 4 years & 10.6 & 14.1 & 10.7 & 14.2 & 74 & \\
\hline 5 years & 10.8 & 14.3 & 10.8 & 14.4 & 74 & \\
\hline 6 years & 11.0 & 14.4 & 11.0 & 14.5 & 74 & \\
\hline 8 years & 11.4 & 14.7 & 11.3 & 14.8 & 75 & \\
\hline 10 years & 11.6 & 15.0 & 11.6 & 15.0 & 76 & \\
\hline 12 years & 11.9 & 15.5 & 11.6 & 15.3 & 77 & \\
\hline 14 years & 12.1 & 16.3 & 11.6 & 15.4 & 77 & \\
\hline 16 years & 12.3 & 17.1 & 11.6 & 15.4 & 78 & \\
\hline
\end{tabular}

MCV, $\mathrm{fL}$

\begin{tabular}{|c|c|c|c|}
\hline & Male & & Female \\
\hline 2.5th & 97.5th & 2.5th & 97.5th \\
\hline 32 & 39 & 32 & 39 \\
\hline
\end{tabular}

$\begin{array}{lllllll}116 & 97 & 118 & 32 & 39 & 32 & 39\end{array}$

$\begin{array}{lllllll}116 & 96 & 117 & 32 & 39 & 32 & 39\end{array}$

$\begin{array}{lllllll}116 & 96 & 117 & 32 & 39 & 32 & 39\end{array}$

$\begin{array}{lllllll}115 & 96 & 117 & 32 & 39 & 32 & 39\end{array}$

$\begin{array}{lllllll}115 & 96 & 117 & 32 & 39 & 32 & 39\end{array}$

$\begin{array}{lllllll}115 & 95 & 117 & 32 & 39 & 32 & 39\end{array}$

$\begin{array}{lllllll}115 & 95 & 116 & 32 & 39 & 32 & 39\end{array}$

$\begin{array}{lllllll}113 & 93 & 115 & 31 & 38 & 31 & 38\end{array}$

$\begin{array}{lllllll}112 & 91 & 114 & 30 & 38 & 31 & 38\end{array}$

$\begin{array}{lllllll}110 & 89 & 112 & 29 & 37 & 30 & 37\end{array}$

$\begin{array}{lllllll}104 & 82 & 106 & 27 & 35 & 27 & 34\end{array}$

$\begin{array}{lllllll}99 & 77 & 100 & 25 & 33 & 26 & 32\end{array}$

$\begin{array}{lllllll}93 & 74 & 95 & 24 & 31 & 25 & 31\end{array}$

$\begin{array}{lllllll}89 & 73 & 91 & 23 & 30 & 24 & 30\end{array}$

$\begin{array}{lllllll}88 & 73 & 90 & 23 & 30 & 24 & 30\end{array}$

$\begin{array}{lllllll}88 & 73 & 90 & 23 & 30 & 24 & 30\end{array}$

$\begin{array}{lllllll}88 & 73 & 90 & 23 & 30 & 24 & 30\end{array}$

$\begin{array}{lllllll}88 & 73 & 90 & 23 & 30 & 24 & 30\end{array}$

$\begin{array}{lllllll}88 & 74 & 89 & 24 & 29 & 24 & 30\end{array}$

$\begin{array}{lllllll}87 & 74 & 89 & 24 & 29 & 24 & 30\end{array}$

$\begin{array}{lllllll}87 & 75 & 88 & 24 & 30 & 25 & 30\end{array}$

$\begin{array}{lllllll}87 & 75 & 88 & 25 & 30 & 25 & 30\end{array}$

$\begin{array}{lllllll}87 & 76 & 89 & 25 & 30 & 25 & 30\end{array}$

$\begin{array}{lllllll}88 & 77 & 89 & 25 & 30 & 26 & 30\end{array}$

$\begin{array}{lllllll}88 & 77 & 91 & 26 & 30 & 26 & 31\end{array}$

$\begin{array}{lllllll}90 & 78 & 92 & 26 & 31 & 26 & 31\end{array}$

$\begin{array}{lllllll}91 & 79 & 94 & 26 & 31 & 26 & 32\end{array}$

$\begin{array}{lllllll}93 & 79 & 96 & 27 & 32 & 26 & 32\end{array}$

Age

MCHC, g/dL

\begin{tabular}{|c|c|c|}
\hline & Male & \\
\hline 2.5th & 97.5th & 2.5th \\
\hline
\end{tabular}

th

\begin{tabular}{|c|c|c|c|}
\hline & Male & & Female \\
\hline 2.5th & 97.5th & 2.5th & 97.5th \\
\hline
\end{tabular}

Red blood cells, $10^{6} / \mu \mathrm{L}$

\begin{tabular}{rrrrr}
\hline & Male & & Female \\
\cline { 1 - 1 } \cline { 5 - 5 } 2.5th & 97.5th & & 2.5th & 97.5th \\
\hline 3.17 & 5.97 & & 3.20 & 5.89 \\
3.15 & 5.96 & & 3.18 & 5.87 \\
3.14 & 5.94 & & 3.17 & 5.85 \\
3.12 & 5.93 & & 3.15 & 5.84 \\
3.10 & 5.92 & & 3.13 & 5.82 \\
3.09 & 5.90 & & 3.12 & 5.81 \\
3.07 & 5.89 & & 3.10 & 5.79 \\
3.06 & 5.88 & & 3.09 & 5.78 \\
2.95 & 5.78 & & 2.98 & 5.67 \\
2.85 & 5.69 & & 2.88 & 5.56 \\
2.73 & 5.56 & 2.76 & 5.41 \\
2.57 & 5.28 & 2.60 & 5.08 \\
2.69 & 5.18 & 2.72 & 4.96 \\
3.07 & 5.21 & 3.07 & 5.00 \\
3.46 & 5.27 & 3.41 & 5.10 \\
3.58 & 5.28 & 3.53 & 5.16 \\
3.60 & 5.28 & 3.55 & 5.17 \\
3.63 & 5.28 & 3.57 & 5.19 \\
3.65 & 5.28 & 3.60 & 5.21
\end{tabular}


(Supplemental Table 4 Continued)

Age

MCHC, $\mathrm{g} / \mathrm{dL}$

Platelets, $1000 / \mu \mathrm{L}$

Red blood cells, $10^{6} / \mu \mathrm{L}$

\begin{tabular}{|c|c|c|c|c|c|c|c|c|c|c|c|c|}
\hline & \multicolumn{2}{|r|}{ Male } & \multicolumn{2}{|r|}{ Female } & \multicolumn{2}{|r|}{ Male } & \multicolumn{2}{|r|}{ Female } & \multicolumn{2}{|r|}{ Male } & \multicolumn{2}{|r|}{ Female } \\
\hline & 2.5th & 97.5th & 2.5th & 97.5th & 2.5 th & 97.5th & 2.5th & 97.5th & 2.5 th & 97.5th & 2.5th & 97.5th \\
\hline 2 years & 31 & 35 & 31 & 35 & 167 & 496 & 185 & 522 & 3.79 & 5.28 & 3.76 & 5.26 \\
\hline 3 years & 31 & 36 & 31 & 35 & 168 & 472 & 183 & 491 & 3.86 & 5.29 & 3.84 & 5.28 \\
\hline 4 years & 31 & 36 & 31 & 35 & 170 & 452 & 183 & 465 & 3.93 & 5.29 & 3.91 & 5.29 \\
\hline 5 years & 31 & 36 & 31 & 35 & 173 & 436 & 183 & 444 & 3.98 & 5.30 & 3.96 & 5.30 \\
\hline 6 years & 31 & 36 & 31 & 35 & 175 & 422 & 184 & 426 & 4.03 & 5.31 & 4.01 & 5.31 \\
\hline 8 years & 32 & 36 & 31 & 36 & 177 & 399 & 183 & 398 & 4.09 & 5.35 & 4.07 & 5.32 \\
\hline 10 years & 32 & 36 & 31 & 36 & 174 & 379 & 177 & 377 & 4.14 & 5.43 & 4.09 & 5.33 \\
\hline 12 years & 32 & 36 & 31 & 36 & 167 & 365 & 169 & 360 & 4.19 & 5.53 & 4.07 & 5.34 \\
\hline 14 years & 32 & 36 & 31 & 35 & 159 & 349 & 162 & 352 & 4.25 & 5.66 & 4.02 & 5.32 \\
\hline 16 years & 32 & 36 & 31 & 35 & 151 & 326 & 154 & 351 & 4.31 & 5.83 & 3.93 & 5.30 \\
\hline
\end{tabular}

Age

Hematocrit, \%

RDWCV, CV

Plasma sodium, mmol/L

\begin{tabular}{|c|c|c|c|c|c|c|c|c|c|c|c|c|}
\hline & \multicolumn{2}{|r|}{ Male } & \multicolumn{2}{|r|}{ Female } & \multicolumn{2}{|r|}{ Male } & \multicolumn{2}{|r|}{ Female } & \multicolumn{2}{|r|}{ Male } & \multicolumn{2}{|r|}{ Female } \\
\hline & 2.5th & 97.5th & 2.5th & 2.5th & 2.5th & 97.5th & 2.5th & 97.5th & 2.5th & 97.5th & 2.5th & 97.5th \\
\hline 0 day & 34.2 & 61.5 & 36.1 & 62.1 & 14.6 & 19.0 & 14.1 & 19.2 & 128 & 144 & 129 & 143 \\
\hline 1 day & 34.0 & 61.2 & 35.9 & 61.8 & 14.5 & 18.9 & 14.1 & 19.1 & 128 & 144 & 129 & 142 \\
\hline 2 days & 33.8 & 61.0 & 35.6 & 61.6 & 14.5 & 18.9 & 14.1 & 19.1 & 128 & 144 & 129 & 142 \\
\hline 3 days & 33.5 & 60.7 & 35.4 & 61.3 & 14.5 & 18.9 & 14.0 & 19.1 & 128 & 143 & 129 & 142 \\
\hline 4 days & 33.3 & 60.5 & 35.2 & 61.0 & 14.4 & 18.9 & 14.0 & 19.0 & 128 & 143 & 129 & 142 \\
\hline 5 days & 33.1 & 60.2 & 35.0 & 60.7 & 14.4 & 18.8 & 13.9 & 19.0 & 128 & 143 & 129 & 142 \\
\hline 6 days & 32.8 & 60.0 & 34.7 & 60.4 & 14.3 & 18.8 & 13.9 & 19.0 & 128 & 143 & 129 & 142 \\
\hline 1 week & 32.6 & 59.7 & 34.5 & 60.2 & 14.3 & 18.8 & 13.9 & 18.9 & 128 & 143 & 129 & 142 \\
\hline 2 weeks & 31.0 & 57.9 & 33.0 & 58.2 & 14.1 & 18.6 & 13.6 & 18.7 & 129 & 142 & 129 & 141 \\
\hline 3 weeks & 29.5 & 56.1 & 31.5 & 56.3 & 13.8 & 18.3 & 13.3 & 18.5 & 129 & 141 & 130 & 141 \\
\hline 1 month & 27.6 & 53.7 & 29.7 & 53.6 & 13.5 & 18.1 & 13.0 & 18.2 & 130 & 140 & 130 & 140 \\
\hline 2 months & 24.5 & 47.0 & 26.4 & 46.4 & 12.6 & 17.3 & 12.1 & 17.2 & 131 & 139 & 131 & 139 \\
\hline 3 months & 24.5 & 42.7 & 25.8 & 41.8 & 12.0 & 16.5 & 11.4 & 16.3 & 132 & 139 & 131 & 140 \\
\hline 4 months & 26.6 & 40.5 & 27.4 & 39.7 & 11.7 & 15.7 & 11.1 & 15.3 & 132 & 140 & 132 & 140 \\
\hline 5 months & 28.9 & 40.1 & 29.3 & 39.7 & 11.8 & 15.3 & 11.2 & 14.9 & 131 & 140 & 132 & 140 \\
\hline 6 months & 29.8 & 40.3 & 30.0 & 40.2 & 11.9 & 15.3 & 11.3 & 14.9 & 131 & 140 & 132 & 140 \\
\hline 8 months & 29.9 & 40.4 & 30.1 & 40.4 & 11.9 & 15.3 & 11.4 & 14.9 & 131 & 140 & 131 & 140 \\
\hline 10 months & 30.1 & 40.5 & 30.3 & 40.6 & 12.0 & 15.3 & 11.4 & 15.0 & 131 & 140 & 131 & 140 \\
\hline 1 year & 30.3 & 40.6 & 30.5 & 40.8 & 12.0 & 15.3 & 11.5 & 15.0 & 131 & 140 & 131 & 140 \\
\hline 2 years & 31.2 & 41.0 & 31.4 & 41.7 & 12.1 & 15.1 & 11.8 & 14.9 & 131 & 141 & 131 & 141 \\
\hline 3 years & 31.7 & 41.3 & 32.0 & 42.0 & 12.1 & 14.8 & 11.9 & 14.6 & 131 & 141 & 132 & 141 \\
\hline 4 years & 32.1 & 41.6 & 32.5 & 42.2 & 12.1 & 14.6 & 12.0 & 14.4 & 132 & 141 & 132 & 141 \\
\hline 5 years & 32.5 & 41.9 & 33.0 & 42.4 & 12.2 & 14.4 & 12.1 & 14.2 & 132 & 141 & 132 & 141 \\
\hline 6 years & 32.9 & 42.3 & 33.4 & 42.7 & 12.2 & 14.3 & 12.1 & 14.0 & 132 & 141 & 132 & 141 \\
\hline 8 years & 33.8 & 43.0 & 34.3 & 43.3 & 12.1 & 14.0 & 12.1 & 13.7 & 133 & 141 & 133 & 142 \\
\hline 10 years & 34.6 & 44.0 & 34.9 & 44.1 & 12.1 & 14.0 & 12.0 & 13.6 & 133 & 141 & 133 & 142 \\
\hline 12 years & 35.4 & 45.3 & 35.4 & 44.7 & 12.0 & 14.0 & 12.0 & 13.6 & 133 & 141 & 133 & 142 \\
\hline 14 years & 36.3 & 47.1 & 35.5 & 45.1 & 12.0 & 14.0 & 11.9 & 13.7 & 133 & 142 & 133 & 141 \\
\hline 16 years & 37.3 & 49.3 & 35.5 & 45.0 & 12.0 & 13.9 & 11.8 & 13.9 & 133 & 142 & 133 & 141 \\
\hline
\end{tabular}

Supplemental Table 4 Calculated indirect reference intervals.

Calculated age-dependent percentiles for each quantity. 


\section{Danksagung}

Ich bedanke mich bei allen, die mich bei meiner Arbeit unterstützt und ohne die sie nicht in der vorliegenden Form vollendet worden wäre. Mein besonderer Dank gilt

Prof. Dr. med. Markus Metzler, der mich seit meinem Studium intensiv in allen Belangen gefördert hat. Von inm und Prof. Dr. rer. nat. Manfred Rauh

ging die Initiative zu dieser Arbeit aus und nur mit ihrer Unterstützung und konstruktiven Kritik konnte sie gelingen.

Dr. rer. nat. Farhad Arzideh und Prof. Dr. med. Rainer Haeckel, die den Algorithmus entwickelten, auf dem diese Arbeit basiert und die sehr viel Wissen und Mithilfe zur Verfügung stellten.

\section{Patricia Schmid,}

für die freundliche Korrektur der Manuskripte.

Prof. Dr. med. Dr. h. c. Wolfgang Rascher, für die konstruktive Mitarbeit an der Promotionsarbeit und die Möglichkeit an seiner Klinik weiter wissenschaftlich aktiv zu sein. 